OPEN ACCESS

Edited by:

Elvira Forte,

Jackson Laboratory, United States

Reviewed by:

Radhika P. Atit,

Case Western Reserve University,

United States

Edward Tredget,

University of Alberta Hospital, Canada

*Correspondence:

Qingfeng Li

dr.liqingfeng@yahoo.com

Tao Zan

zantaodoctor@yahoo.com

${ }^{\dagger}$ These authors have contributed equally to this work

Specialty section:

This article was submitted to Integrative Physiology, a section of the journal Frontiers in Physiology

Received: 14 April 2021

Accepted: 16 June 2021

Published: 15 July 2021

Citation:

Huang X, Khoong Y, Han C, Su D,

Ma H, Gu S, Li Q and Zan T (2021) Targeting Dermal Fibroblast Subtypes in Antifibrotic Therapy: Surface Marker as a Cellular Identity or a Functional Entity? Front. Physiol. 12:694605. doi: 10.3389/fphys.2021.694605

\section{Targeting Dermal Fibroblast Subtypes in Antifibrotic Therapy: Surface Marker as a Cellular Identity or a Functional Entity?}

\author{
Xin Huang ${ }^{\dagger}$, Yimin Khoong', Chengyao Han, Dai Su, Hao Ma, Shuchen Gu, Qingfeng Li* \\ and Tao Zan*
}

Department of Plastic and Reconstructive Surgery, Shanghai Ninth People's Hospital, School of Medicine, Shanghai Jiao Tong University, Shanghai, China

Fibroblasts are the chief effector cells in fibrotic diseases and have been discovered to be highly heterogeneous. Recently, fibroblast heterogeneity in human skin has been studied extensively and several surface markers for dermal fibroblast subtypes have been identified, holding promise for future antifibrotic therapies. However, it has yet to be confirmed whether surface markers should be looked upon as merely lineage landmarks or as functional entities of fibroblast subtypes, which may further complicate the interpretation of cellular function of these fibroblast subtypes. This review aims to provide an update on current evidence on fibroblast surface markers in fibrotic disorders of skin as well as of other organ systems. Specifically, studies where surface markers were treated as lineage markers and manipulated as functional membrane proteins are both evaluated in parallel, hoping to reveal the underlying mechanism behind the pathogenesis of tissue fibrosis contributed by various fibroblast subtypes from multiple angles, shedding lights on future translational researches.

Keywords: fibroblast subtypes, fibroblast heterogeneity, fibrosis, surface marker, antifibrotic therapy

\section{INTRODUCTION}

Fibroblast (Fb), as a vital interstitial cell, is involved in a wide variety of biological functions such as conferring structural support to tissues, secreting extracellular matrix (ECM), participating in tissue damage repair and immune responses (Lynch and Watt, 2018). Besides, Fb is also the chief effector cell in fibrotic diseases. Abnormal $\mathrm{Fb}$ function, such as cellular hyperproliferation and excessive extracellular matrix deposition, can directly mediate tissue fibrosis (Jiang and Rinkevich, 2020). Fb has always been thought to be stable and unitary in terms of its composition and function. In the past, based on the histological characteristics of the skin, $\mathrm{Fb}$ was mainly classified into three types, namely papillary layer, deep reticular layer, hair shaft and papillary region of the hair follicle (Lynch and Watt, 2018). Unfortunately, due to the lack of surface markers that can effectively distinguish different fibroblast subtypes, accurate separation of different fibroblast subtypes has always been an obstacle, and has greatly restricted the further in-depth study of the functional characteristics of this complex cell population.

In recent years, development of omic sequencing technology, especially in single-cell omics, has enabled people to understand the phenotype and functional characteristics of cells on the single-cell level, thereby increased the depth and accuracy in our understanding of the complex cell populations (Prakadan et al., 2017). With the help of omics technology, fibroblast subpopulations 
were studied in detail and were found to be highly heterogeneous in their compositions. Previously characterized papillary and reticular $\mathrm{Fb}$ were demonstrated to contain a complex population of cells that do not share a specific marker (Ascensión et al., 2020; Vorstandlechner et al., 2020). At present, several studies have been performed to uncover the $\mathrm{Fb}$ heterogeneity in normal human skin tissues. Tabib et al. (2018) discovered that dermal $\mathrm{Fb}$ can be divided into two main subpopulations characterized by SFRP2 and FMO1; and into several subpopulations according to their expression of CRABP1, COL11A1, FMO2, PRG4, and C2ORF40. Philippeos et al. (2018) performed transcriptome sequencing on the papillary and reticular dermal tissues, and revealed several pan-Fb markers, including CD90, plateletderived growth factor receptor (PDGFR, including PDGFR $\alpha$ and PDGFR $\beta$ ). Besides, CD39, COL6A5, COL23A1, APCDD1, HSPB3, and WIF1 were found highly expressed in papillary $\mathrm{Fb}$, while CD36 was specifically highly expressed in reticular $\mathrm{Fb}$ (Philippeos et al., 2018). Using flow cytometry, Korosec et al. (2019) found that Fbs characterized by fibroblast activation protein (FAP) positive and CD90 negative phenotype are enriched in the papillary dermis and expressed both PDPN and NTN1, displayed active proliferation, and are relatively resistant to adipogenic differentiation. On the other hand, FAP-CD90+ Fbs expressed high levels of ACTA2, MGP, PPAR $\gamma$, and CD36 and possessed a higher adipogenic potential, contributing to features of reticular Fbs.

The research on $\mathrm{Fb}$ heterogeneity in healthy skin is still very much in its infancy. Based on currently available evidence, it is acknowledged that pan-Fb surface markers of human skin $\mathrm{Fb}$ are CD90, PDGFR $\alpha$ and PDGFR $\beta$, while the surface markers of Fb subtypes are FAP, CD26, CD36, and CD39. These surface markers hold the promise of future antifibrotic therapies by targeting $\mathrm{Fb}$ subtypes with small molecule inhibitors or inhibitory antibodies. However, evidence regarding the functional characteristics and dynamic alteration of $\mathrm{Fb}$ subtypes in both healthy or fibrotic skin is still scarce. More importantly, there is a discrepancy between Fb surface markers as lineage markers or as functional entities in the previous studies, which further complicates the interpretation of cellular functions, hampering future development of targeted therapy (Jacob et al., 2012). In this review, we aim to summarize the current evidence of $\mathrm{Fb}$ surface markers in fibrotic disorders of skin as well as of other organ systems. Specifically, we would like to compare the role of these surface markers in fibrotic diseases as lineage markers or as functional membrane proteins. Besides, antifibrotic therapies targeting certain $\mathrm{Fb}$ subtypes or particular surface marker proteins would be evaluated, hoping to shed light on the significance of these $\mathrm{Fb}$ subtypes during the fibrotic process, and to provide some valuable insights for future translational research.

\section{PAN FIBROBLAST SURFACE MARKERS}

\section{CD90}

CD90, also known as Thy1, is a glycosylphosphatidylinositolanchored glycoprotein that is expressed on the surfaces of $\mathrm{T}$ cells, neuronal cells, endothelial cells, mesenchymal stem cells and fibroblasts (Jiang and Rinkevich, 2018). CD90 regulates cell adhesion and migration, and plays an important role in the processes of axon growth, $\mathrm{T}$ cell activation, cell proliferation and apoptosis regulation, and tumor cell migration (Shaikh et al., 2016). In human dermis, it was shown that CD90 is widely expressed in all skin layers, including papillary dermis, reticular dermis and hypodermis, thus it is also known as a pan-Fb surface marker (Driskell et al., 2013; Philippeos et al., 2018). However, Korosec et al. (2019) stated that the uppermost papillary Fbs possessed a CD90 negative phenotype. Besides, CD90 cannot clearly distinguish between dermal mesenchymal stem cells and dermal Fbs, suggesting that CD90 alone is not an accurate marker to define $\mathrm{Fbs}$ in general or its subtypes (Jiang and Rinkevich, 2018).

$\mathrm{CD} 90+\mathrm{Fbs}$ were found to be accumulated in the collagen packed loci of several fibrotic diseases, including systemic sclerosis (Nazari et al., 2016), cholestatic liver injury (Katsumata et al., 2017), pathological scarring (Ho et al., 2019) and contracted capsule induced by tissue expander implantation (Hansen et al., 2017). Moreover, the expression level of CD90 in Fbs was positively correlated with the severity of tissue fibrosis (Nazari et al., 2016; Katsumata et al., 2017), suggesting the positive role of CD90+ Fbs in the pathogenesis of these diseases. CD90+ Fbs were also regarded to be functionally activated as myofibroblast marker $\alpha$-smooth muscle actin ( $\alpha$ SMA) and ECM related genes were both highly expressed (Hansen et al., 2017; Ho et al., 2019). Besides, CD90+ Fbs inhibited ECM degradation through the upregulation of Tissue Inhibitors of Metalloproteinases-1 (TIMP1) (Katsumata et al., 2017).

However, CD90 exerted contradictory functions in different disease models. For instance, the depletion of CD90 would halt fibrosis in prosthesis-induced scar formation (Hansen et al., 2017) and idiopathic pulmonary fibrosis (IPF) (Fiore et al., 2015). These antifibrotic effects may be attributed to the inhibition of the association between CD90 and the $\alpha v \beta 3$ integrins upon CD90 depletion, further blocking Src family kinase recruitment and Rho signaling activation (Gerber et al., 2013; Fiore et al., 2015). In contrast, in IPF, CD90 was found to be lowly expressed in the fibroblastic foci (Sanders et al., 2008). Also, Lung Fbs from CD90 knockout mice showed increased cell proliferation and collagen deposition, revealing antifibrotic properties of CD90 (Nicola et al., 2009). The inconsistencies across studies suggested that: (1) CD90+ Fb may act differently during fibrosis formation depending on the organ system involved; (2) CD90 is widely expressed in multiple mesenchymal cells, thus global depletion of CD90 cells may not be limited to just CD90+ Fbs, but also other CD90+ cells, thereby significantly complicating the interpretation of results (Rege and Hagood, 2006).

Small molecular compounds such as OSU-CG5 and monoclonal antibodies targeting CD90 have already been used to inhibit CD90+ tumor cells in solid or hematological malignancy (Ishiura et al., 2010; Chen et al., 2015). However, to date none has been tested for treatment of fibrotic diseases. Apart from directly targeting CD90 per se or CD90+ cells, other treatment options which inhibits the differentiation of endothelial cells into CD90+ Fb (Wei et al., 2020) or disrupts the interaction between CD90 and integrin $\alpha \nu$ (Tan et al., 2019), 
might also achieve desirable therapeutic effects on tissue fibrosis (Figure 1).

\section{Platelet-Derived Growth Factor Receptor (PDGFR)}

Platelet-derived growth factor receptor belongs to the receptor tyrosine-specific protein kinase family. It possesses intrinsic kinase activity and is widely expressed in Fbs, endothelial cells and myoepithelial cells (Lynch and Watt, 2018). The binding of PDGF isoforms to PDGFR dimers $\alpha \alpha, \alpha \beta, \beta \beta$ would trigger autophosphorylation of PDGFRs on different tyrosine residues and subsequent activation of downstream signaling pathways, regulating cell proliferation, apoptosis, differentiation, migration, and angiogenesis (Östman, 2017; Klinkhammer et al., 2018). It plays important roles in physiological processes including growth and development, and wound repair; as well as in pathological processes such as tumorigenesis (Pietras et al., 2003).

In normal human skin, PDGFR $\alpha$ and PDGFR $\beta$ are indiscriminately expressed in the papillary and reticular dermis (Philippeos et al., 2018). It has been reported that upon muscle and skin injury, a lineage of ADAM12+ cells would be induced into a distinct subset of PDGFR $\alpha+$ cells, namely the ADAM12+ PDGFR $\alpha+$ Fbs which mediates scarring repair by producing collagen (Dulauroy et al., 2012). Similar fibrogenic potential of PDGFR $\alpha+$ cells has also been observed in other organs. It has been reported that PDGFR $\alpha+$ progenitor cells give rise to major matrix-producing $\mathrm{Fbs}$ in tendon repair (Harvey et al., 2019), liver fibrosis (Ramachandran et al., 2019), and kidney and heart ischemic injury (Santini et al., 2020). PDGFenriched microenvironment would also contribute to tissue fibrosis as seen in Duchenne muscular dystrophy (DMD), where PDGFR $\alpha+$ Sca1 + CD45- mesenchymal progenitor cells would be activated into tissue remodeling cells after receiving PDGFAA ligands from the surrounding muscle cells (Ieronimakis et al., 2016). Besides, PDGFR $\alpha$, which is also expressed in the adipose precursor cells (Driskell and Watt, 2015; Marcelin et al., 2017), would be activated, resulting in the transformation of cells into PDGFR $\alpha+C D 9^{\text {high }}$ Fbs that act as the pivotal cells in tissue metabolism and white adipose tissue (WAT) fibrosis (Marcelin et al., 2017).

Profibrotic effect of PDGF signaling pathway has been evaluated in multiple organs including liver (Hayes et al., 2014; Ramachandran et al., 2019), skin (Olson and Soriano, 2009), kidney (Ostendorf et al., 2003) and heart (Pontén et al., 2003). Other than activating the classic fibrogenic ERK, AKT, and $\mathrm{NF}-\kappa \mathrm{B}$ pathways which ultimately resulting in excessive tissue fibrosis (Kocabayoglu et al., 2015; Higashi et al., 2017), PDGFR signaling, specifically PDGF $\beta$ signaling is also accountable for functional activation of Fbs as shown by upregulation of $\alpha \mathrm{SMA}$ and profibrotic cytokines such as matrix metalloproteinases (MMPs) and TIMPs (Czochra et al., 2006). In addition, PDGF$\mathrm{BB}$ is involved in promoting the secretion of extracellular vesicles containing PDGFR $\alpha$, which in turn facilitates the activation of cellular function of hepatic stellate cells, promoting liver fibrosis (Kostallari et al., 2018).

As the critical role of PDGF/PDGFR signaling in promoting tissue fibrosis has been well documented, numerous antifibrotic approaches targeting this pathway have been developed (Papadopoulos et al., 2018). Basically, these treatment strategies are mainly divided into three categories (Papadopoulos et al., 2018): (1) sequestering PDGF ligands or inhibiting their binding

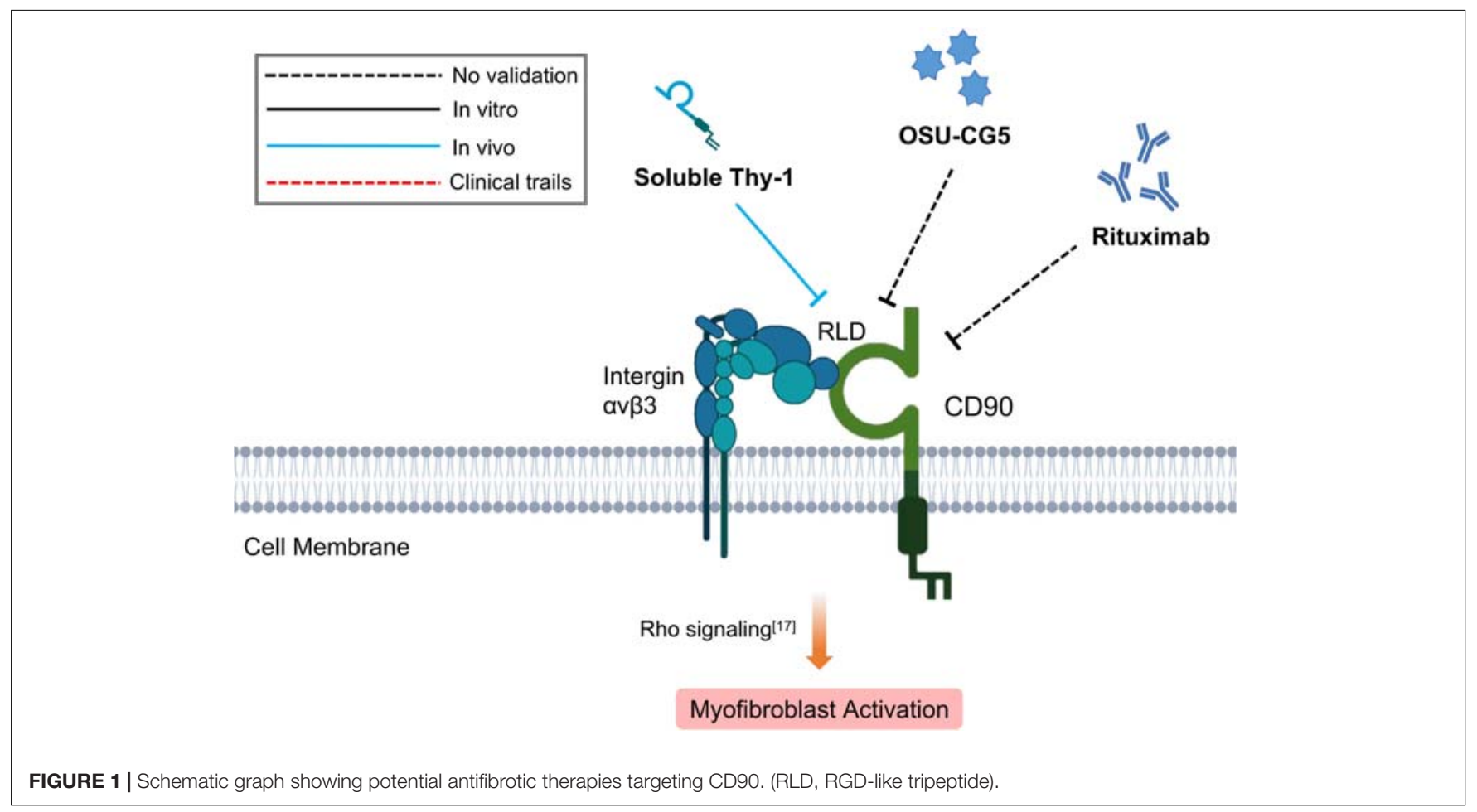


to their respective receptors using neutralizing antibodies or aptamers, which are single-stranded DNA or RNA molecules that possess selective binding affinity to the PDGF ligands, consequently blocking the activation of PDGFRs; (2) inhibiting ligand-receptor interactions by blocking the extracellular domain of PDGFR with antibodies or small molecular drugs; (3) blocking the activation of intracellular tyrosine kinase or downstream pathways of PDGFR signaling with low molecular weight inhibitors.

Hao et al. (2012) demonstrated that PDGF-B kinoid immunogen, a kind of PDGF-B-derived epitope-carrier protein heterocomplexes, would elicit the production of neutralizing anti-PDGF-B autoantibodies responsible for the suppression of proliferation and activation of the hepatic stellate cells (HSCs), which would ultimately inhibit liver fibrosis. Similar antifibrotic effects can also be achieved through direct administration of PDGF-BB specific neutralizing antibody (MOR8457) (Yoshida et al., 2014; Kuai et al., 2015) or soluble dominant negative PDGFR $\beta$ (Borkham-Kamphorst et al., 2004), as demonstrated in mice model of hepatic fibrosis. For small molecular drugs, tyrosine kinase inhibitors (TKIs) have been proven to be one of the most promising antifibrotic therapies that target the enzymatic activity of PDGFR (Papadopoulos et al., 2018), such as in hepatic (Liu et al., 2011; Shaker et al., 2011) and pulmonary (Vuorinen et al., 2007; Fleetwood et al., 2017) fibrosis. With respect to skin fibrosis, Imatinib inhibited the proliferation and production of ECM, including collagen 1 and fibronectin in vitro in dermal Fbs obtained from systemic sclerosis patients (Distler et al., 2007; Soria et al., 2008). In vivo, Imatinib administration reduced dermal thickening and prevented the differentiation of resting Fbs into myofibroblasts in TSK-1 mice and bleomycin-induced dermal fibrosis (Akhmetshina et al., 2009). Similar protective effects on dermal fibrotic diseases would also be observed with Sunitinib, Dasatinib, and Nilotinib in vivo (Akhmetshina et al., 2008; Kavian et al., 2012). However, clinical trials evaluating the therapeutic efficacy of Imatinib on systemic sclerosis gave multifarious results (Khanna et al., 2011; Spiera et al., 2011; Prey et al., 2012; Fraticelli et al., 2014; Gordon et al., 2014). Kay and High (2008) first reported progressive improvement of skin thickening and tethering following initiation of Imatinib in two patients with nephrogenic systemic fibrosis. However, recurrence of skin lesions were observed shortly after therapy withdrawal (Kay and High, 2008). In 26 systemic sclerosis interstitial lung disease, the use of low dose Imatinib (200 mg/day) for 6 months was associated with good drug tolerance and stabilized lung function, however, without significant effects on skin lesions (Fraticelli et al., 2014). Another phase 2 trial showed that the use of Imatinib $400 \mathrm{mg} /$ day would improve both forced vital capacity and skin thickening (Spiera et al., 2011; Gordon et al., 2014). Yet, using similar dose of Imatinib (400 mg/day), Prey et al. (2012) failed to demonstrate therapeutic efficacy of Imatinib in regards to impact on dermal thickness, pulmonary function and quality of life. By further increasing the dose to $600 \mathrm{mg} /$ day, Khanna et al. (2011) only reported a trend toward improved lung function and skin thickness, but were associated with significant adverse effects. The reasons for the inconsistencies between these studies are unclear, but may be due to drug dosage, treatment duration, and patient groups and thus requires further investigation (Khanna et al., 2011). In conclusion, the curative effect of TKIs in the treatment of fibrotic disease requires further studies to confirm its effectiveness (Figure 2).

It has been reported that the auto-phosphorylated PDGFR and downstream activation of Ras, RAF pro-oncogene serine/threonine protein kinase (RAF-1), mitogen-activated protein kinase (MEK) and extracellular signal-regulated protein kinase (ERK) signaling pathways facilitate the progression of hepatic fibrosis (Ying et al., 2017). Sorafenib, a potent inhibitor of PDFGR $\beta$ and RAF kinase, has been demonstrated to effectively reduce the portal pressure and portosystemic collaterals in a rat model of portal hypertension, thereby reducing the level of intrahepatic fibrosis (Figure 2) (Mejias et al., 2009).

\section{SURFACE MARKERS FOR FIBROBLAST SUBTYPES}

\section{Fibroblast Activation Protein (FAP)}

Fibroblast activation protein is an integral membrane glycoprotein of the serine proteases family, possessing dual collagenase and dipeptidase activities, which aids in the degradation of gelatin, type I collagen and a variety of dipeptides (Kelly, 2005). Although FAP and CD26 both belong to the same S9B prolyl oligopeptidase subfamily and are highly homologous, they are not interchangeable (Kelly, 2005). Previous studies reported that FAP was highly expressed in the cancer associated fibroblasts (CAFs), which in turn mediated cancer invasion and metastasis through the degradation of extracellular matrix (Kalluri and Zeisberg, 2006).

In normal human skin, FAP + CD90- Fbs are commonly regarded as the papillary Fbs, which showed increased proliferation potential and lower adipogenic differentiation as compared to the reticular Fbs (Korosec et al., 2019). FAP is also found to be highly expressed in the collagen-accumulated loci of several fibrotic diseases including keloid (Dienus et al., 2010), liver fibrosis (Levy et al., 2002), myocardial infarction (Tillmanns et al., 2015), lung fibrosis (Acharya et al., 2006), Crohn's disease (Truffi et al., 2018), and arthritis (Croft et al., 2019). FAP + Fbs generally highly express $\alpha$ SMA as observed in infarcted heart tissues of human and mice model, suggesting these Fbs express an activated contractive phenotype (Tillmanns et al., 2015). Further, Avery et al. found that the expression of FAP and $\alpha$ SMA is regulated by ECM composition, elasticity and transforming growth factor- $\beta$ (TGF- $\beta$ ) signaling (Avery et al., 2018). In fibronectin-enriched matrix, TGF- $\beta$ preferentially upregulates the expression of FAP; whereas in Collagen 1enriched matrix, $\alpha$ SMA is induced instead (Avery et al., 2018). $\mathrm{FAP}^{\mathrm{Hi}} \alpha \mathrm{SMA}^{\text {low }}$ and $\mathrm{FAP}^{\text {low }} \alpha \mathrm{SMA}^{\mathrm{Hi}}$ Fbs displayed distinct functional differences in that the former has a higher capacity of ECM deposition, while the latter showed a more contractive potential (Avery et al., 2018). In addition, FAP has been reported to be vital for various cellular functions like cell proliferation (Croft et al., 2019), migration (Wang et al., 2005; Dienus et al., 2010), invasion (Wang et al., 2005; Dienus et al., 2010), apoptosis 


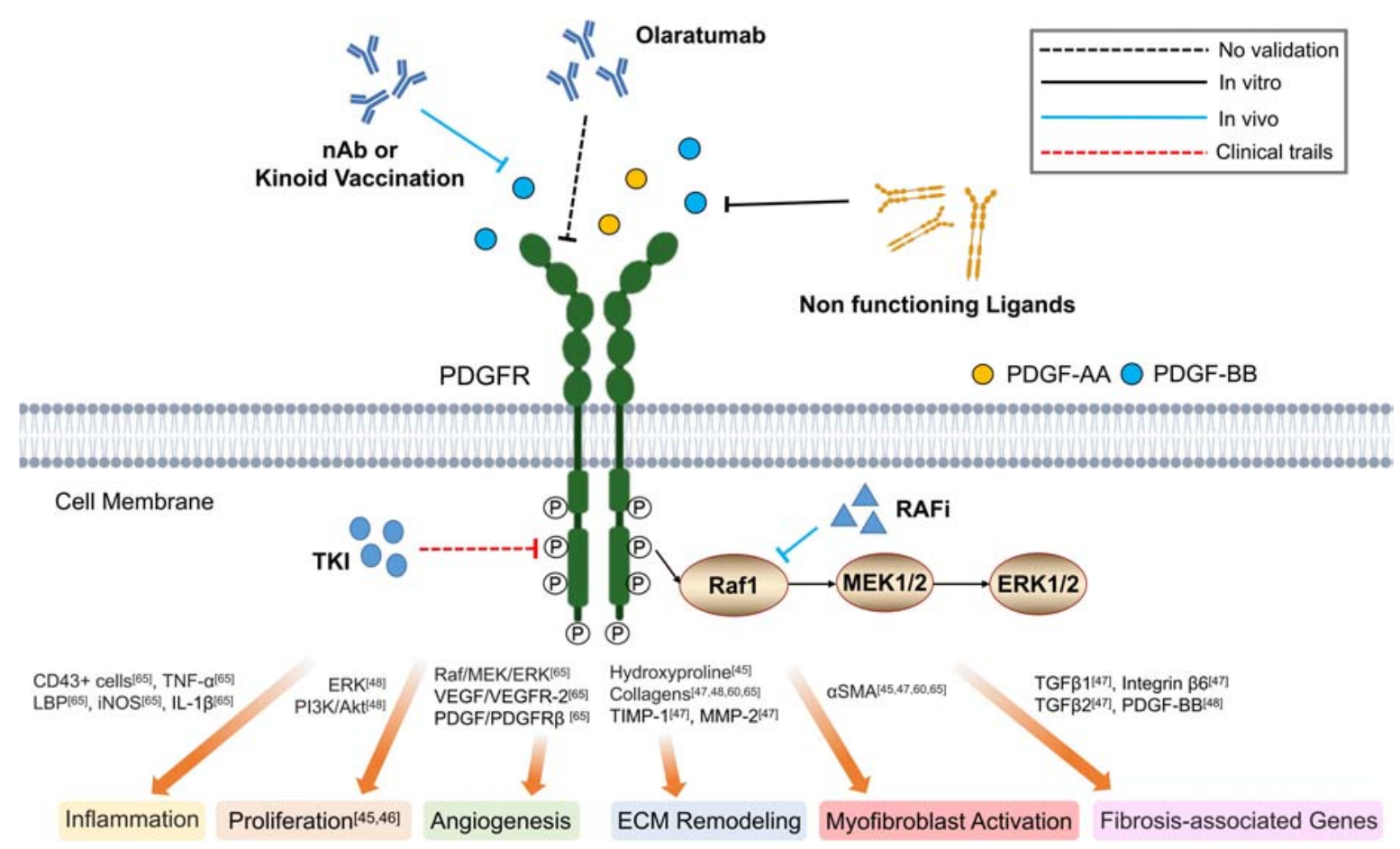

FIGURE 2 | Schematic graph showing potential antifibrotic therapies targeting PDGFR. (nAb, neutralizing antibody; TKI, tyrosine kinase inhibitor; RAFi, Raf kinase inhibitor; LBP, lipopolysaccharide-binding protein; TNF- $\alpha$, tumor necrosis factor- $\alpha$; iNOS, inducible nitric oxide synthase; IL-1 $\beta$, interleukin-1 $\beta$; PI3K, phosphoinositide 3-kinase; Akt, also known as PKB, protein kinase B; VEGF, vascular endothelial growth factor; VEGFR-2, vascular endothelial growth factor receptor-2; TIMP-1, tissue inhibitors of metalloproteinases-1; MMP-2, matrix metalloproteinase-2; $\alpha \mathrm{SMA}, \alpha$-smooth muscle actin; ECM, extracellular matrix).

(Wang et al., 2005) and production of profibrotic proteins (such as TIMPs) (Truffi et al., 2018). The therapeutic effects of FAP targeted approaches are partly attributed to the regulation of cellular functions of the culprit FAP expressing cells. However, it has been noted that the choice of animal model or intervention approach would influence the final interpretation of therapeutic effect by targeting the FAP+ Fbs (Kimura et al., 2019). For instance, FAP + cell depletion by T cells expressing FAP chimeric antigen receptors or global FAP knockout showed increased level of pulmonary fibrosis in bleomycin-induced lung fibrosis, but had only minimal effects on the Ad-TGF $\beta$ induced model (Kimura et al., 2019). These phenomena highlight the fact that different fibrosis models may have distinct mechanisms of action upon initiating insults and that FAP + Fbs may have adapted to different functions throughout the fibrotic processes.

Although various FAP targeting strategies have been established, including inhibition of enzymatic activity of FAP, depletion of FAP expressing cells and targeted delivery of cytotoxic compounds, their applications in fibrotic diseases have been limited so far (Figure 3) (Busek et al., 2018).

Targeted inhibition of FAP using H2N-Gly-Pro diphenylphosphonate, an irreversible inhibitor of FAP (Gilmore et al., 2006), has been shown to impair the invasiveness of keloid Fbs in vitro (Dienus et al., 2010). Similarly, Talabostat mesylate (PT-100), an extracellular dipeptidylpeptidases inhibitor, would reduce bleomycin-induced lung injury by downregulating FAP and MMP-12 expression and increasing macrophage activation
(Egger et al., 2017). Moreover, oral administration of L-glutamyl L-boroproline (PT-630), a more specific FAP inhibitor, in murine model of rheumatoid arthritis has found to exert inhibitory effects on the invasiveness of synovial Fbs (Ospelt et al., 2010). However, PT-630 which is relatively non-selective often inhibits both CD26 and FAP activities, thus the development of more selective FAP inhibitors is warranted, as well as the assessment of their antifibrotic activity in preclinical and clinical trials (Jacob et al., 2012). Recently, chimeric antigen receptors (CARs) engineered $\mathrm{T}$ cells that specifically target the FAP have been demonstrated to prevent cardiac fibrosis and improve cardiac function in vivo, suggesting a novel direction to develop anti-FAP therapies (Aghajanian et al., 2019) (Figure 3).

\section{CD26}

CD26 (also known as dipeptidyl peptidase IV, DPP IV) is a highly conserved type II transmembrane serine exopeptidase that hydrolyzes proline or alanine from the $\mathrm{N}$-terminus of a broad range of polypeptides (Hu and Longaker, 2016). CD26 is widely expressed in a variety of cells and tissues, and participates in the regulation of nutrient absorption, tumor invasion and metastasis, and many other physiological and pathological processes (Ibegbu et al., 2009).

The role of CD26 in renal fibrosis (Takagaki et al., 2017), cardiac fibrosis (Bando and Murohara, 2016), hepatic fibrosis (Itou et al., 2013), wound healing and cutaneous diseases (Hu and Longaker, 2016; Patel et al., 2020) has been extensively discussed 


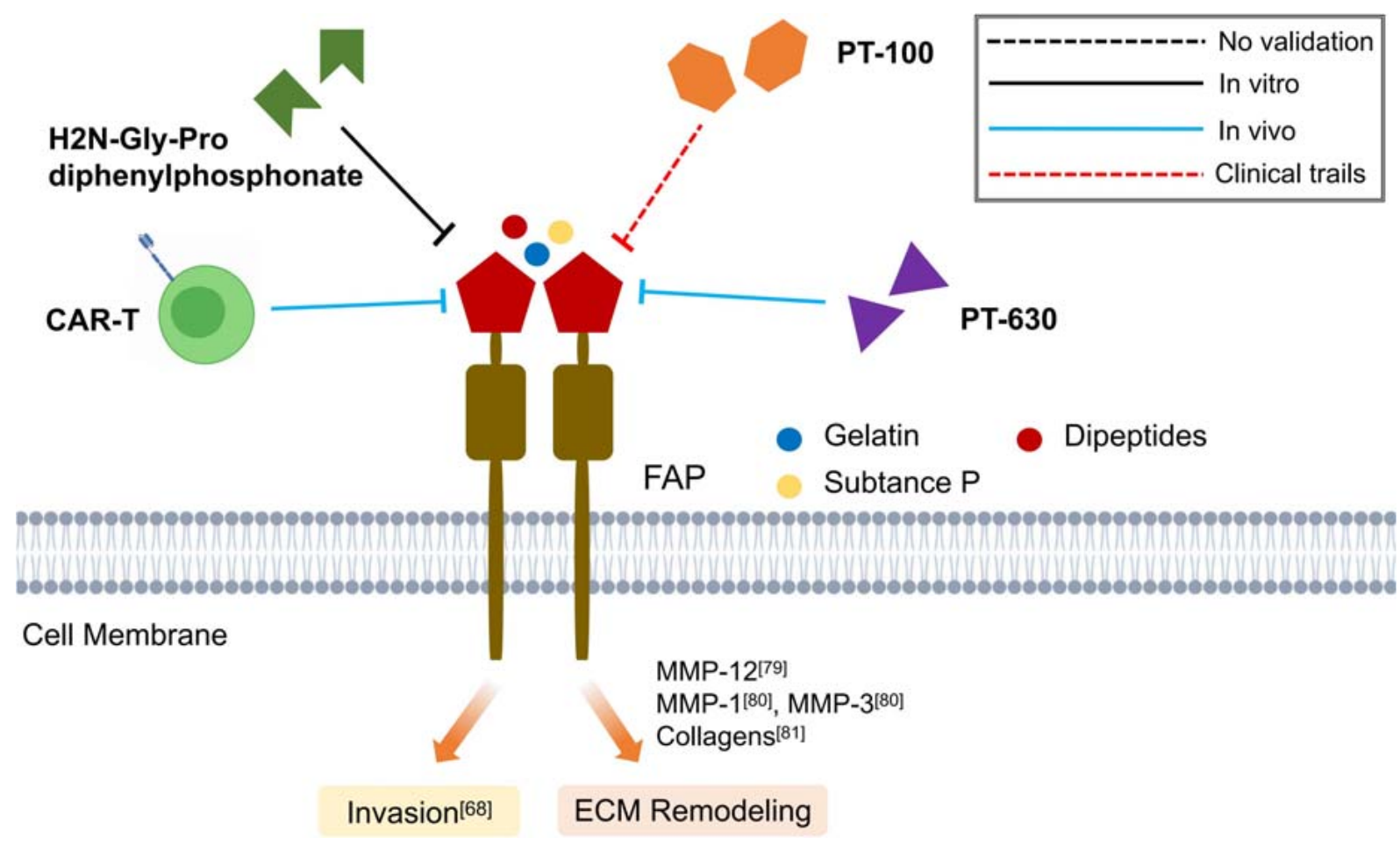

FIGURE 3 | Schematic graph showing potential antifibrotic therapies targeting FAP. (CAR-T, chimeric antigen receptors engineered T cell; MMP, matrix metalloproteinase; ECM, extracellular matrix).

by recent reviews. Here, we would like to mainly address the advances of CD26 in skin fibrosis. The profibrotic nature of $\mathrm{CD} 26$ can be inspected from two intriguing observations: Dipeptidyl Peptidase-4 inhibitors (DPP4-Is) are novel oral hypoglycemics drugs used in clinical practice that work by blocking the enzymatic function of DPP-4 (Panchapakesan and Pollock, 2015). In a retrospective study, the occurrence rate of pathological scars (keloids and hypertrophic scars) after median sternotomy was significantly reduced in patients who have received DPP4-I treatment (Suwanai et al., 2020). Furthermore, $\mathrm{CD} 26+\mathrm{Fb}$ population appeared more abundant in the human skin than in the gingiva, which may be associated with a better regeneration and less scarring property of gingiva (Mah et al., 2017). During the scarring process, fewer CD26+ Fbs was found in the regenerated gingival wounds as compared to the hypertrophic-like scars (Mah et al., 2017). Through rigorous lineage tracing experiments, Rinkevich et al. (2015) demonstrated that Engrailed-1 lineage-positive Fbs are the major cells responsible for matrix deposition in wound healing in mice skin. Moreover, cytometric screening identified CD26 as a surface marker for $94 \%$ of Engrailed-1 lineage-positive Fbs, and inhibition of CD26 with Diprotin A has resulted in mitigation of skin scarring (Rinkevich et al., 2015).

In contrast to the mice skin, studies of CD26 in human skin are relatively inconsistent (Philippeos et al., 2018; Tabib et al., 2018; Korosec et al., 2019; Vorstandlechner et al., 2020). Tabib et al. (2018) and Vorstandlechner et al. (2020) proposed that CD26+ Fbs that accumulate in both papillary and reticular layers have been demonstrated to be the major $\mathrm{Fb}$ subpopulation responsible for ECM assembly in normal skin and healing wounds in humans (Vorstandlechner et al., 2020; Worthen et al., 2020). In contrast, Philippeos et al. (2018) showed that CD26+ Fbs are enriched in the reticular dermis; while Korosec et al. (2019) believed that $\mathrm{CD} 26+\mathrm{Fbs}$ are located in the papillary dermis but are also detectable in other dermal layers. Although consensus on the localization of $\mathrm{CD} 26+$ Fbs in human skin has yet to be reached, CD26+ Fbs derived from keloid, a typical fibrotic skin disorder after injury, demonstrated markedly elevated ability of cell proliferation and migration; greater expression of inflammatory and fibrotic factors such as TGF- $\beta 1$, insulin growth factor- 1 (IGF1 ), and interleukin-6 (IL-6); and increased production of ECM components such as collagen 1, collagen 3 and fibronectin (Xin et al., 2017). In systemic sclerosis, CD26+ Fbs expressed high level of myofibroblast marker $\alpha$ SMA and collagen (Soare et al., 2020). The functional status of CD26 decides on the regulation of a series of cellular functions like cell proliferation, migration and collagen production. CD26 inhibition by genetic knockout or DPP4-I exerted potent antifibrotic effects in bleomycin-induced skin fibrosis (Soare et al., 2020).

It has been reported that the inhibition of CD26 exerted hypoglycaemic, anti-inflammatory, and antifibrotic effects (Panchapakesan and Pollock, 2015). The mechanism behind the antifibrotic role of CD26 is complex and has been investigated in several aspects. Primarily, it has been reported that CD26 blockage using established small molecular drugs would abrogate the classic TGF- $\beta 1$ signaling pathways in hepatic 
(Kaji et al., 2014; Zhang et al., 2019; Khalil et al., 2020), pulmonary (Xu et al., 2018), renal (Seo et al., 2019; Kim et al., 2020), and adipose tissue (Marques et al., 2018) fibrosis. In high glucose culture environment, DPP4-I would decrease the expression of phosphorylated protein of the IGF/Akt/mTOR signaling pathway in hypertrophic scar-derived $\mathrm{Fbs}$, inhibiting their trans-differentiation into myofibroblasts (Li et al., 2019). In addition, DPP4-I would reduce the level of inflammatory signals including NLR Family Pyrin Domain Containing 3 (NLRP3) inflammasome, endoplasmic reticulum (ER) stress and proinflammatory cytokine including IL-1 $\beta$, IL-6, and tumor necrosis factor $\alpha$ (TNF- $\alpha$ ) in the mice model of renal (Seo et al., 2019) and hepatic fibrosis (Jung et al., 2014). Apart from mediating the fibrotic and inflammatory pathways, DPP4-I also attenuated fibrogenesis by modulating the cellular status and phenotype including lipotoxicity-induced apoptosis (Lee et al., 2020) and endothelial-mesenchymal transition (EndMT) (Kanasaki et al., 2014; Suzuki et al., 2017; Xu et al., 2018). Aroor et al. (2015) reported the use of DPP4-I as a therapeutic rescue in patients with hepatic steatosis through the enhancement of mitochondrial glucose utilization and triacylglycerol secretion/export, thereby suppressing the accumulation of hepatic triacylglycerol and diacylglycerol. Taken together, these suggest that the metabolic regulation property of DPP4-I would be one of the main factors accounting for its antifibrotic effect.

Until now, DPP4-I has been proven to exhibit prominent anti-fibrotic effects on liver (Jung et al., 2014; Kaji et al., 2014; Aroor et al., 2015; Zhang et al., 2019; Khalil et al., 2020; Lee et al., 2020), lung (Suzuki et al., 2017; Xu et al., 2018), kidney (Kanasaki et al., 2014; Gangadharan Komala et al., 2016; Uchii et al., 2016; Seo et al., 2019; Kim et al., 2020), adipose tissue (Marques et al., 2018) and skin (Long et al., 2018; Li et al., 2019; Soare et al., 2020). These studies signify the potential use of DPP4-I in combating fibrotic diseases (Figure 4). However, further clinical trials are still required to verify its effect. What's more, the comparison of different types of DPP4-I regarding their antifibrotic effectiveness on various organ system is scarce in current researches. In addition, a more detailed knowledge concerning the dosage and adverse effects of a particular type of DPP4-I may be beneficial for future clinical application.

\section{CD36}

CD36 (also known as scavenger receptor B2), is identified as a single chain transmembrane glycoprotein with two transmembrane domains and an extracellular region (Yang et al., 2017). The versatile function of CD36 is attributed to its wide range of ligands, which mainly includes the long-chain fatty acids, oxidized lipids and phospholipids, advanced oxidation protein products (AOPPs), thrombospondin and advanced glycation end products (AGEPs) (Yang et al., 2017). This ligand-receptor complex on the response element suggested the important role of CD36 in lipid metabolism, immunological response, inflammatory stress response, fibrosis and angiogenesis and arthrosclerosis (Febbraio et al., 2001; Sweetwyne and MurphyUllrich, 2012).

CD36 is expressed in multiple cells including renal tubule epithelial cells, podocytes, macrophages, microvascular endothelial cells and dermal Fbs (Febbraio et al., 2001; Philippeos et al., 2018). It has been reported that LinCD90 + CD36+ Fbs, which mainly located in the reticular dermis, possessed an inflammatory phenotype that included higher expression of $\alpha \mathrm{SMA}, \mathrm{MGP}, \operatorname{PPAR} \gamma$; greater secretion of ECM and inflammatory factors; increased sensitivity upon interferon- $\gamma$ (IFN- $\gamma)$ stimulation; and stronger adipogenic differentiation (Philippeos et al., 2018; Korosec et al., 2019). In IPF, a group of CD36 + CD97+ Fbs has been identified in the remodeled areas of IPF tissue but with low expression of $\alpha \mathrm{SMA}$ and ECM, suggesting that these Fbs are quiescent and are non-ECM producers in pulmonary fibrosis (Heinzelmann et al., 2018).

Although CD36 + Fbs have not shown fibrogenic phenotype, CD36 receptor would, however, associate with thrombospondin1 (TSP-1)/latent TGF $\beta 1$ (L-TGF $\beta 1$ ) and facilitate the release of mature TGF- $\beta 1$, initiating tissue fibrotic response (Yehualaeshet et al., 2000). The inhibition of this CD36/TSP-1/L-TGF $\beta 1$ regulatory pathway has been demonstrated to exert antifibrotic effects in lung (Yehualaeshet et al., 2000; Wang et al., 2009) and kidney (Yang et al., 2007; Pennathur et al., 2015) fibrotic diseases. On the other hand, the lipid transportation function of CD36 also contributed to tissue fibrogenesis. In tubular epithelial cell-specific CD36 overexpressed transgenic mice model, Kang et al. (2015) discovered the association of the increased long-chain fatty acid transportation with increasing aSMA and collagen 1 expression, which then facilitates the development of renal fibrosis. On the contrary, Rabinowitz and Mutlu (2019) and Zhao et al. (2019) found that the transplantation of CD36-overexpressed fibroblasts into the mouse skin would effectively reduce the radiation-induced skin fibrosis by activating fatty acid utilization while inhibiting glycolysis pathway. Therefore, there remains controversies concerning the relationship between fatty acid transportation function of CD36 and fibrosis as the choice of animal models and interventions would lead to completely distinct outcomes. On the other hand, the inflammation regulatory role of CD36 has also been reported in the CD36 expressing macrophages that have been reported to promote chronic kidney fibrogenesis by facilitating the activation of nuclear factor- $\kappa \mathrm{B}(\mathrm{NF}-\kappa \mathrm{B})$ signaling and increasing oxidative stress (Okamura et al., 2009). The binding of lipoproteins, a biological ligand, to CD36 allows the activation of Toll-like receptors (TLRs), SodiumPotassium Adenosine Triphosphatase $(\mathrm{Na}+/ \mathrm{K}+$ ATPase), the NLRP3 inflammasome, protein kinase $\mathrm{C}$-nicotinamide adenine dinucleotide phosphate oxidase (NAPDH) oxidase, Src-family kinases (Scr/Lyn/Fyn), mitogen-activated protein kinases, and TGF- $\beta$ signaling pathways (Yang et al., 2017). As such, synthetic amphipathic helical peptides (SAHPs) can mimic the domain of lipoprotein and bind to the CD36 without exerting activation effects (Souza et al., 2016). In mice models of nephrectomy and angiotensin II-induced chronic renal fibrosis, SAHP 5A decreased the expression of inflammation-associated genes and attenuated the progression of glomerular sclerosis and interstitial fibrosis, thereby providing renal protection. However, due to the relatively low selectivity of SAHP 5A which also targets other scavenger receptors (SR BI/II), a 

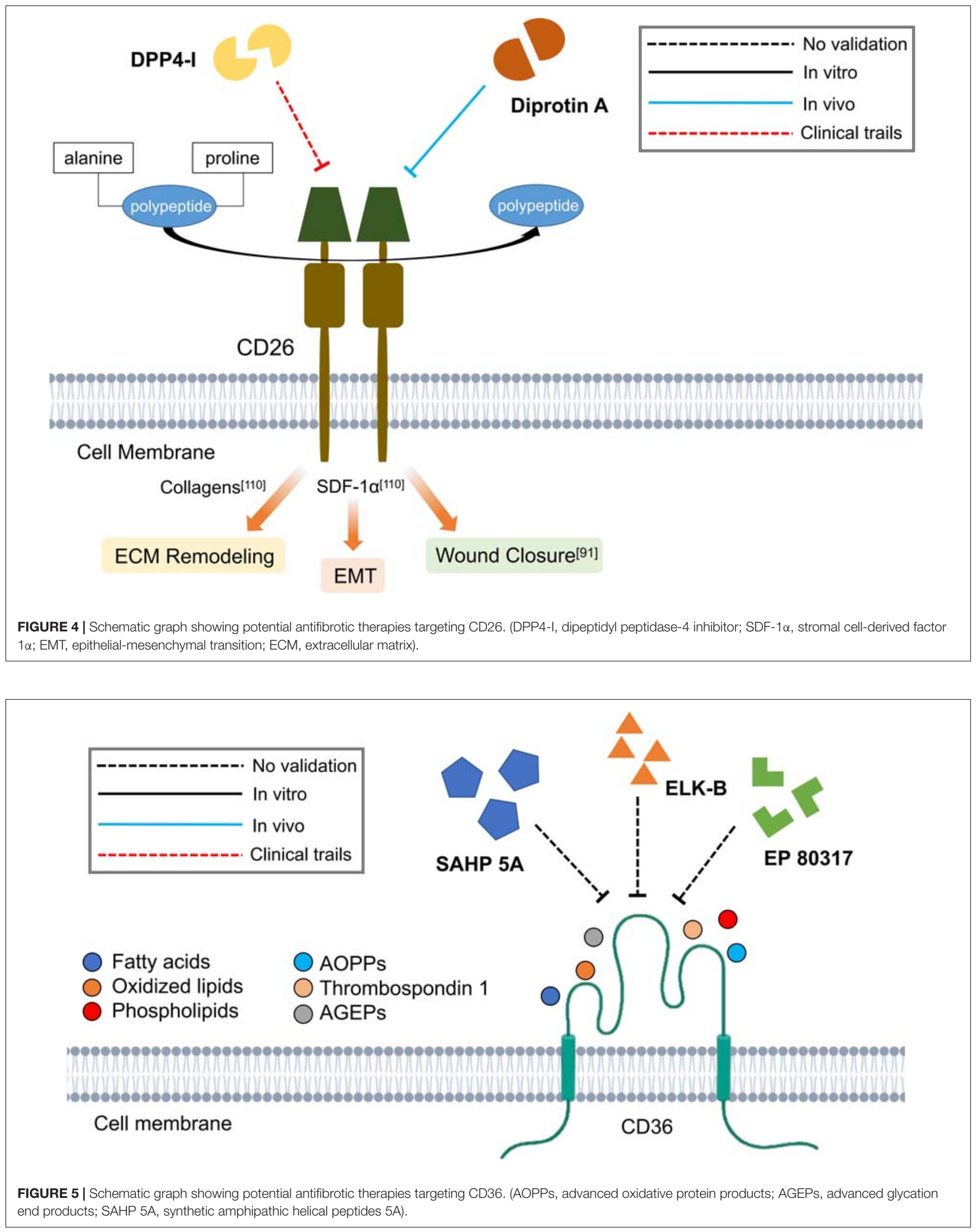
TABLE 1 | The function of Fb subtypes in tissue fibrosis.

\begin{tabular}{|c|c|c|c|}
\hline Fb subtypes & Models and diseases & description & Effect \\
\hline CD90 + CD34- & Human scars (Ho et al., 2019) & Colocalize with $\alpha$ SMA and procollagen-1 & Fibrogenic \\
\hline CD90 + podoplanin + CD34- & $\begin{array}{l}\text { Human SSC (Nazari et al., } \\
\text { 2016) }\end{array}$ & Expanded cell population & Fibrogenic \\
\hline CD90 + CD45- & $\begin{array}{l}\text { Murine cholestatic liver injury } \\
\text { (Katsumata et al., 2017) }\end{array}$ & High level of expression of $\alpha$ SMA, collagen-1 and TIMP-1 & Fibrogenic \\
\hline PDGFRa + CDghigh & $\begin{array}{l}\text { Murine obesity-induced WAT } \\
\text { fibrosis (Marcelin et al., 2017) }\end{array}$ & Give rise to profibrotic cells; modulate omental WAT fibrogenesis & Fibrogenic \\
\hline PDGFR $\alpha+$ TPPP3+ & $\begin{array}{l}\text { Murine tendon injury (Harvey } \\
\text { et al., 2019) }\end{array}$ & Fibrotic scars formation in healing tendons & Fibrogenic \\
\hline PDGFR $\alpha+$ & $\begin{array}{l}\text { Human cirrhotic liver; murine } \\
\text { CCl4-induced liver fibrosis } \\
\text { (Ramachandran et al., 2019) }\end{array}$ & Expanded cell population in fibrotic niche & Fibrogenic \\
\hline PDGFR $\alpha+$ & $\begin{array}{l}\text { Murine ischemic injury (Santini } \\
\text { et al., 2020) }\end{array}$ & Promotion of skeletal muscle fibrosis upon ischemic injury. & Fibrogenic \\
\hline PDGFR $\alpha+$ Sca1 + CD45- & $\begin{array}{l}\text { Murine DMD (leronimakis et al., } \\
\text { 2016) }\end{array}$ & Expanded cell population; major matrix-forming Fbs & Fibrogenic \\
\hline PDGFR $\alpha+$ ADAM12+ & $\begin{array}{l}\text { Murine muscle and skin injury } \\
\text { (Dulauroy et al., 2012) }\end{array}$ & Major fraction of collagen-overproducing cells & Fibrogenic \\
\hline FAP + CD90- & $\begin{array}{l}\text { Human skin (Korosec et al., } \\
\text { 2019) }\end{array}$ & $\begin{array}{l}\text { High proliferative potential; low adipogenic potential; enriched in the } \\
\text { papillary dermis }\end{array}$ & Non-fibrogenic \\
\hline FAP+ & $\begin{array}{l}\text { Human and rat myocardial } \\
\text { infarction (Tillmanns et al., } \\
\text { 2015) }\end{array}$ & $\begin{array}{l}\text { Located in peri-infarct area with co-expression of prolyl-4-hydroxylase } \beta \text {, } \\
\alpha S M A \text {, and vimentin }\end{array}$ & Fibrogenic \\
\hline CD26 + Sca1- & $\begin{array}{l}\text { Murine skin (Driskell et al., } \\
\text { 2013; Philippeos et al., 2018) }\end{array}$ & $\begin{array}{l}\text { Papillary Fbs with upregulation of Wnt pathway related genes (Philippeos } \\
\text { et al., 2018); large fraction of dermal Fbs in adult mice (Driskell et al., 2013) }\end{array}$ & Non-fibrogenic \\
\hline CD26+ & $\begin{array}{l}\text { Murine (Rinkevich et al., 2015) } \\
\text { and human wound } \\
\text { (Vorstandlechner et al., 2020; } \\
\text { Worthen et al., 2020) }\end{array}$ & $\begin{array}{l}\text { Major scar-forming Engrailed1+ Fbs (Rinkevich et al., 2015); main } \\
\text { ECM-producing Fbs during the remodeling phase of wound healing } \\
\text { (Vorstandlechner et al., 2020; Worthen et al., 2020) }\end{array}$ & Fibrogenic \\
\hline CD26+ & Human keloid (Xin et al., 2017) & $\begin{array}{l}\text { Expended cell population; upregulated proliferation, invasion and } \\
\text { expression of profibrotic genes }\end{array}$ & Fibrogenic \\
\hline Lin-CD90 + CD36+ & $\begin{array}{l}\text { Human skin (Philippeos et al., } \\
\text { 2018; Korosec et al., 2019) }\end{array}$ & $\begin{array}{l}\text { Localize in lower reticular dermis and hypodermis; high adipogenic } \\
\text { potential; high expression of ECM and inflammatory related genes }\end{array}$ & Inflammatory \\
\hline CD36 + CD97+ & $\begin{array}{l}\text { Human IPF (Heinzelmann et al., } \\
\text { 2018) }\end{array}$ & Low cell proliferation rate; low expression of $\alpha \mathrm{SMA}$ and ECM & Non-fibrogenic \\
\hline Lin-CD90 + CD39+ & $\begin{array}{l}\text { Human and mice skin } \\
\text { (Philippeos et al., 2018; } \\
\text { Korosec et al., 2019) }\end{array}$ & $\begin{array}{l}\text { Enriched in papillary dermis; low adipogenic potential; low expression of } \\
\text { ECM and inflammatory related genes }\end{array}$ & Non-fibrogenic \\
\hline
\end{tabular}

SSC, systemic sclerosis; WAT, white adipose tissue; DMD, duchenne muscular dystrophy; IPF, idiopathic pulmonary fibrosis.

more specific CD36 binding SAHP, namely ELK-SAHPs, has been synthesized (Yang et al., 2017). Among them, ELK$\mathrm{B}$ has been shown to improve lung function in the mice model of sepsis by effectively reducing pulmonary infiltration (Bocharov et al., 2016). Another strategy to inhibit the function of CD36 is by using hexapeptide growth hormone-releasing peptides (GHRPs) analog, namely EP 80317. EP 80317 has been found to protect against atherosclerosis progression (Marleau et al., 2005) and myocardial ischemia/reperfusion injury (Bessi et al., 2012). Nevertheless, the above therapies targeting the CD36 are currently under preclinical animal studies and have only been validated in inflammatory and fibrotic diseases of the kidney, lung and heart. Further studies are warranted to verify the anti-fibrosis effect of targeting CD36 in fibrotic diseases of other organ systems (Figure 5). Considering the pleiotropic effects of CD36, a deeper knowledge regarding the cellular specificity of $\mathrm{CD} 36$ function would be necessary for a better development of pharmaceutical strategy (Yang et al., 2017).

\section{CD39}

CD39 (also known as ectonucleoside triphosphate diphosphohydrolase-1, ENTPD1) is an integral cell membrane glycoprotein that exhibit extracellular nucleotide hydrolase activity (Faas et al., 2017). CD39 converts extracellular adenosine triphosphate (ATP) to the adenosine monophosphate (AMP), which is then converted to adenosine (ADO) by CD73 (Faas et al., 2017). The phosphohydrolysis of ATP to AMP is a rate-limiting step in ADO generation (Faas et al., 2017). Philippeos et al. (2018) first uncovered the use of CD39 as a marker for papillary Fb subtype and demonstrated that CD39+ Fbs exhibited higher proliferation rate and can better support epidermal growth in comparison with $\mathrm{CD} 36+$ reticular Fbs. On the contrary, papillary CD39+ Fbs showed lower expression level of ECM and 
TABLE 2 | The function of surface markers per se in tissue fibrosis.

\begin{tabular}{|c|c|c|c|c|}
\hline Markers & Diseases & Intervention and models & Mechanism & Effect \\
\hline \multirow[t]{4}{*}{ CD90 } & $\begin{array}{l}\text { Periprosthetic capsular (Hansen et al., } \\
\text { 2017) }\end{array}$ & $\begin{array}{l}\text { Lentiviral depletion; scar-derived } \\
\text { Fbs }\end{array}$ & Collagen production; myofibroblast activation & Profibrotic \\
\hline & IPF (Fiore et al., 2015) & $\begin{array}{l}\text { Plasmid overexpression and } \\
\text { lentiviral knockdown; human and } \\
\text { mice lung Fbs }\end{array}$ & $\begin{array}{l}\text { CD90 and } \alpha v \beta 3 \text { integrins interaction; mechanosensitive Rho } \\
\text { signaling pathway }\end{array}$ & Profibrotic \\
\hline & Lung development (Nicola et al., 2009) & Thy $-1^{-/-}$transgenic mice & $\begin{array}{l}\text { Cell proliferation; production of collagen and elastin; TGF- } \beta \text { signaling } \\
\text { pathway }\end{array}$ & Antifibrotic \\
\hline & IPF (Sanders et al., 2008) & $\begin{array}{l}\text { DNA methyltransferase Inhibitors; } \\
\text { rat and human lung Fbs }\end{array}$ & Methylation-regulated expression of CD90; myofibroblast activation & Antifibrotic \\
\hline \multirow[t]{4}{*}{$\mathrm{PDGFR} \alpha / \beta$} & $\begin{array}{l}\text { Systemic fibrosis (Olson and Soriano, } \\
\text { 2009) }\end{array}$ & $\begin{array}{l}\text { PDGFR } \alpha \text { knockin mice in } \\
\text { Ink4a/Arf-deficient background }\end{array}$ & Growth of connective tissue; collagen production & Profibrotic \\
\hline & Liver fibrosis (Hayes et al., 2014) & $\begin{array}{l}\text { PDGFR } \alpha \text { GFP reporter mice; } \\
\text { PDGFR } \alpha \text { heterozygous mice }\end{array}$ & Expression of PDGFR $\alpha$ and fibrogenic genes; collagen deposition & Profibrotic \\
\hline & $\begin{array}{l}\text { Liver fibrosis (Kocabayoglu et al., } \\
\text { 2015) }\end{array}$ & 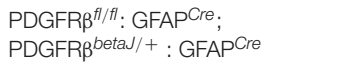 & $\begin{array}{l}\text { Expression of collagen and } \alpha \mathrm{SMA} \text {; ERK, AKT, and NF-kB signaling } \\
\text { pathways }\end{array}$ & Profibrotic \\
\hline & Liver fibrosis (Czochra et al., 2006) & $\begin{array}{l}\text { Transgenic mice overexpressing } \\
\text { PDGF-B in the liver }\end{array}$ & $\begin{array}{l}\text { Myofibroblast activation; collagen deposition; production of MMP-2, } \\
\text { MMP-9, and TIMP-1 }\end{array}$ & Profibrotic \\
\hline \multirow[t]{3}{*}{ FAP } & Lung fibrosis (Kimura et al., 2019) & $\begin{array}{l}\text { FAP targeting CAR-T cells; FAP } \\
\text { knockout mice }\end{array}$ & Collagen production; myofibroblast activation; leukocyte infiltration & Contradictory \\
\hline & Crohn's disease (Truffi et al., 2018) & $\begin{array}{l}\text { FAP targeting antibody; primary } \\
\text { mucosal myofibroblasts }\end{array}$ & Collagen and TIMP-1 production; myofibroblast migration & Profibrotic \\
\hline & Liver injury (Wang et al., 2005) & $\begin{array}{l}\text { Plasmid overexpression; HSC cell } \\
\text { line }\end{array}$ & Cell adhesion, migration, invasion and apoptosis & Profibrotic \\
\hline \multirow[t]{4}{*}{ CD26 } & Systemic sclerosis (Soare et al., 2020) & $\begin{array}{l}\text { DPP4-knockout and DPP4-I; } \\
\text { murine model of } \\
\text { bleomycin-induced fibrosis }\end{array}$ & $\begin{array}{l}\text { Cell proliferation and migration; expression of collagen and } \\
\text { contractile proteins; TGF- } \beta \text { /ERK signaling pathway }\end{array}$ & Profibrotic \\
\hline & Hypertrophic scar (Li et al., 2019) & DPP4-I; HSF & Myofibroblast differentiation; IGF/Akt/mTOR signaling pathway & Profibrotic \\
\hline & Keloid (Thielitz et al., 2008) & $\begin{array}{l}\text { Lys }\left[\mathrm{Z}\left(\mathrm{NO}_{2}\right)\right] \text {-thiazolidide and } \\
\left.\text { Lys[Z( }\left(\mathrm{NO}_{2}\right)\right] \text {-pyrrolidide; } \\
\text { keloid-derived Fbs }\end{array}$ & $\begin{array}{l}\text { Cell proliferation; expression of TGF- } \beta \text { and procollagen type I; } \\
\text { mitogen-activated protein kinases pp38 and pERK1/2 signaling } \\
\text { pathway }\end{array}$ & Profibrotic \\
\hline & $\begin{array}{l}\text { Diabetic Wound Healing (Long et al., } \\
\text { 2018) }\end{array}$ & $\begin{array}{l}\text { DPP4-I; human fibroblast cell line; } \\
\text { murine model of diabetic wounds; } \\
\text { patients with refractory ulcers }\end{array}$ & Collagen deposition; SDF-1 $\alpha$ production; keratinocyte EMT & Profibrotic \\
\hline \multirow[t]{8}{*}{ CD36 } & $\begin{array}{l}\text { Pulmonary fibrosis (Yehualaeshet } \\
\text { et al., 2000) }\end{array}$ & $\begin{array}{l}\text { CD36 inhibitory peptide; rt model } \\
\text { of bleomycin-induced fibrosis }\end{array}$ & Production of TGF- $\beta 1$, inflammatory factors, and ECM & profibrotic \\
\hline & $\begin{array}{l}\text { Skin fibrosis (Rabinowitz and Mutlu, } \\
\text { 2019; Zhao et al., 2019) }\end{array}$ & $\begin{array}{l}\text { Transplantation of CD } 36^{h i g h} \mathrm{Fb} \text { or } \\
\mathrm{CD} 36^{K O} \mathrm{Fb} \text {; murine model of } \\
\text { radiation-induced skin fibrosis }\end{array}$ & Fatty acid oxidation; degradation of collagen-1; ECM accumulation & Antifibrotic \\
\hline & Renal fibrosis (Kang et al., 2015) & $\begin{array}{l}\text { Pax8rtTA/TRE-CD36 } \\
\text { double-transgenic mice }\end{array}$ & Intracellular lipid accumulation; expression of collagen-1 and $\alpha \mathrm{SMA}$ & Profibrotic \\
\hline & Renal fibrosis (Souza et al., 2016) & $\begin{array}{l}\text { CD36 antagonist (apolipoprotein } \\
\text { Al-mimetic peptide } 5 \mathrm{~A}) \text {; murine } \\
\text { model of unilateral ureteral } \\
\text { obstruction }\end{array}$ & $\begin{array}{l}\text { Macrophage infiltration; expression of inflammasome genes; } \\
\text { interstitial fibrosis }\end{array}$ & Profibrotic \\
\hline & Renal fibrosis (Okamura et al., 2009) & $\mathrm{CD} 6^{-/-}$transgenic mice & $\begin{array}{l}\text { Regulation of oxidative stress; myofibroblast activation; NF-кB } \\
\text { signaling pathway }\end{array}$ & Profibrotic \\
\hline & $\begin{array}{l}\text { Chronic kidney injury (Pennathur et al., } \\
\text { 2015) }\end{array}$ & CD36-deficient mice & $\begin{array}{l}\text { Production of intracellular bioactive oxidized lipids, TNF- } \alpha \text { and } \\
\text { TGF- } \beta 1\end{array}$ & Profibrotic \\
\hline & Renal tubule fibrosis (Yang et al., 2007) & $\begin{array}{l}\text { siRNA knockdown; LLCPK1 cell } \\
\text { line }\end{array}$ & Albumin production; expression of TGF- $\beta 1$ and fibronectin & Profibrotic \\
\hline & Lung fibrosis (Wang et al., 2009) & $\begin{array}{l}\text { Lentiviral depletion; rat silicosis } \\
\text { model }\end{array}$ & Activation of L-TGF- $\beta 1$; production of hydroxyproline and ECM & Profibrotic \\
\hline \multirow[t]{6}{*}{ CD39 } & $\begin{array}{l}\text { Chronic renal Fibrosis (Roberts et al., } \\
\text { 2017) }\end{array}$ & $\begin{array}{l}\text { CD39 over-expressing transgenic } \\
\text { mice }\end{array}$ & Adenosine generation & Profibrotic \\
\hline & Skin fibrosis (Fernández et al., 2013) & CD39 knockout mice & $\begin{array}{l}\text { Adenosine generation; production of collagen and profibrotic } \\
\text { cytokines; myofibroblast activation }\end{array}$ & Profibrotic \\
\hline & Pancreatitis (Künzli et al., 2008) & $\begin{array}{l}\text { CD39-null mice; PSC with CD39 } \\
\text { depletion }\end{array}$ & Cell proliferation; expression of procollagen- $\alpha 1$ and IFN- $\gamma$ & Profibrotic \\
\hline & Chronic renal injury (Wang et al., 2012) & $\begin{array}{l}\text { CD39 over-expressing transgenic } \\
\text { mice }\end{array}$ & $\begin{array}{l}\text { CD25+ Treg cells; production of urinary protein and serum creatinine } \\
\text { level }\end{array}$ & Antifibrotic \\
\hline & $\begin{array}{l}\text { Chronic kidney injury (Roberts et al., } \\
\text { 2016) }\end{array}$ & $\begin{array}{l}\text { CD39 over-expressing transgenic } \\
\text { mice }\end{array}$ & No protective effects on renal fibrosis & Non-effective \\
\hline & $\begin{array}{l}\text { Sclerosing cholangitis (Rothweiler } \\
\text { et al., 2019) }\end{array}$ & $\begin{array}{l}\text { Global or myeloid-specific } \\
\text { CD39-deficient mice }\end{array}$ & $\begin{array}{l}\text { Collagen production; expression of profibrotic genes } \operatorname{Tgf}-\beta 1, \operatorname{Tnf}-\alpha \text {, } \\
\text { and } \alpha \text {-Sma }\end{array}$ & Antifibrotic \\
\hline
\end{tabular}

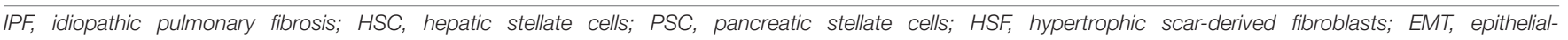
mesenchymal transition. 
inflammatory cytokine, lower adipogenic capacity and are less responsive to inflammatory signals such as IFN- $\gamma$, as compared to CD36+ reticular Fbs (Philippeos et al., 2018).

At present, such studies investigating the cellular function of $\mathrm{CD} 39+\mathrm{Fbs}$ are scarce, especially regarding their role in the process of tissue fibrosis. However, the role of CD39 protein per se in fibrotic diseases have been studied and showed competing results. On one hand, CD39 hyperfunction caused the accumulation of extracellular ADO and facilitated the activation of ADO signaling pathway, resulting in tissue fibrosis (Roberts et al., 2017). In renal ischemia-reperfusion injury models, overexpression of CD39 in the transgenic mice showed significantly more severe renal fibrosis via upregulating $\mathrm{ADO}$ and stimulating profibrotic downstream pathways through interaction with adenosine A2B receptors (Roberts et al., 2017). Consistently, antifibrogenic effects of CD39 depletion have been observed in bleomycin-induced skin fibrosis (Fernández et al., 2013) and cyclosporin-induced pancreatitis (Künzli et al., 2008) models, probably through modulating the accumulation of ADO (Fernández et al., 2013) and the expression of profibrotic factors (Fernández et al., 2013)and pro-collagen proteins (Künzli et al., 2008). However, other studies argued that the fibrogenic nature of CD39 appeared to be quite inconsistent between organ systems and fibrosis induction methods (Wang et al., 2012; Roberts et al., 2016; Rothweiler et al., 2019). For instance, in the Adriamycin-induced nephropathy model, transplantation of CD39 overexpressing CD25+ regulatory $\mathrm{T}$ cells showed renal protective effects by attenuating ATP-induced cell apoptosis and inflammation (Wang et al., 2012). Moreover, global CD39 overexpression showed no difference in fibrotic parameters in the unilateral ureteric obstructive mice model, which is inconsistent with that reported in the renal ischemia-reperfusion injury mice models (Roberts et al., 2016; Roberts et al., 2017). Similar discordance has also been observed in hepatic and biliary system where global CD39 depletion attenuated pancreatitis related fibrosis (Künzli et al., 2008) yet exacerbated 3,5diethoxycarbonyl-1,4-dihydrocollidine (DDC) induced biliary fibrosis (Rothweiler et al., 2019).

The reason for the inconsistency between these studies may be various: (1) Firstly, CD39-mediated purinergic signaling pathway is relatively intricate. Both $\mathrm{P} 1$ receptor sensing ADO and $\mathrm{P} 2$ receptor sensing ATP have been reported for their profibrotic role (Burnstock et al., 2012; Ferrari et al., 2016). The hyperfunction of CD39 would result in decreased ATP signaling and enhanced ADO signaling, so the outcome in different tissues or cells is reliant on the superposition of the activation states of the two kinds of receptors (Roberts et al., 2016); (2) Secondly, due to the diverse distribution patterns of $\mathrm{P} 1$ and $\mathrm{P} 2$ receptors and their subtypes in different tissues, the functional changes of CD39 would serve different outcomes in different tissues (Ferrari et al., 2016); (3) Finally, the underlying pathogenesis of fibrotic diseases in different organ systems are distinct, and CD39 may not necessarily be crucial for every type of tissue fibrosis.

To date, several components are available for CD39 targeting, which include the small molecular drugs ARL 67156 trisodium salt and POM-1 (Fang et al., 2016; Yang et al., 2020), and the monoclonal antibody IPH5201 (Perrot et al., 2019). These targeted treatments have shown promising safety profile and therapeutic potential in the regulation of inflammatory response and tumor microenvironment (Fang et al., 2016; Perrot et al., 2019; Yang et al., 2020). However, there is still a lack of studies evaluating their application in fibrotic process, and is definitely worthy of further exploration (Figure 6).

\section{SUMMARY AND PERSPECTIVES}

The advances of high-throughput sequencing technologies have greatly facilitated the investigation on tissue fibrosis, a multiplexed process involving different cell types and factors.

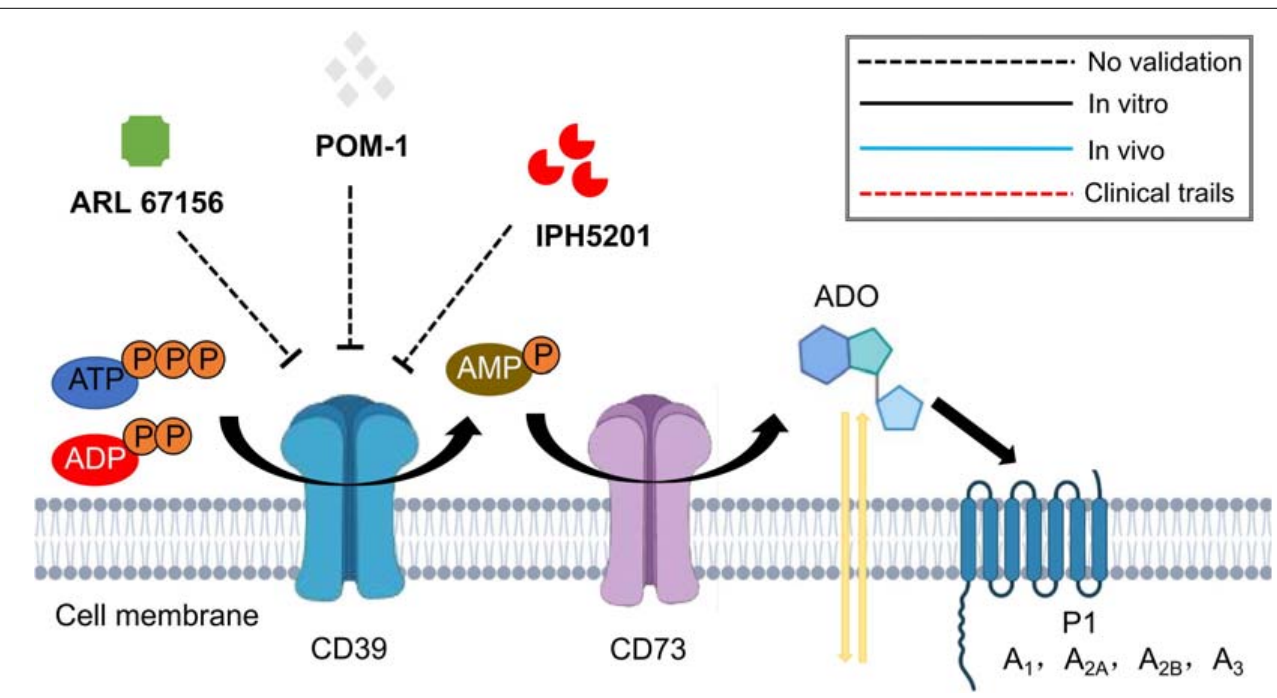

FIGURE 6 | Schematic graph showing potential antifibrotic therapies targeting CD39. (ATP, adenosine triphosphate; ADP, adenosine diphosphate; AMP, adenosine monophosphate; ADO, adenosine). 
In this review, we focused on several surface markers of human dermal Fbs identified in recent years and discussed their respective roles as lineage markers or functional entity in fibrotic diseases. Since the initial discovery, more references are available concerning the role of Fbs defined by CD90, FAP, PDGFR $\alpha / P D G F R \beta$ and CD26 solely, or in combination with other markers. However, only Fbs defined by PDGFR $\alpha /$ PDGFR $\beta$ or CD26 showed consistent fibrogenic potential between studies and appeared in accordance with the molecular function of surface markers per se (see Tables 1, 2). As there are limited literatures on the more recently identified $\mathrm{Fb}$ markers like CD36 and CD39, this demands further researches to investigate their respective roles in fibrotic diseases. Moreover, the function of both of these membrane bound proteins showed comprehensive regulatory network in tissue fibrosis and distinct results across different organs, complicating the interpretation of their biological functions. Surface membrane proteins are considered as the ideal therapeutic targets as they own extracellular domains for ligand binding (Bansal et al., 2016). However, the surface marker does not necessarily account for all of the functional dysregulation of certain $\mathrm{Fb}$ subtype. Therefore, an in depth profiling to investigate the key functional targets that characterize Fb subtypes is still required to provide a better and more effective targeting strategy.

At the same time, there are also some methodological and technical difficulties at this stage: (1) Most Fb subtype surface markers are co-expressed, thus it is challenging to manipulate and to perform research on a specific group of Fbs (Ascensión et al., 2020). (2) It has been suggested that the phenotype of $\mathrm{Fb}$ subtypes requires a specific in vivo microenvironment (Korosec et al., 2019), which is, however, hard to maintain after in vitro culture, indicating that functional profiling directly after cell isolation might provide more reliable information than in vitro experiments. (3) Many newly discovered $\mathrm{Fb}$ subtypes still lack verification on their selective tissue localization. Emerging techniques like imaging mass cytometry and spatial transcriptomics (Giesen et al., 2014; Vickovic et al., 2019) can provide the possibility for combined analysis of functional sequencing and spatial profiling data. (4) Since most of mechanistic studies of $\mathrm{Fb}$ subtypes so far are based on animal models, in view of the limited conservation of $\mathrm{Fb}$ subtypes between human and mice skin (Philippeos et al., 2018), verification of the function of $\mathrm{Fb}$ subtypes or related therapies using human samples, cells or humanized animals is undoubtedly essential and should be the main focus

\section{REFERENCES}

Acharya, P. S., Zukas, A., Chandan, V., Katzenstein, A. L., and Puré, E. (2006). Fibroblast activation protein: a serine protease expressed at the remodeling interface in idiopathic pulmonary fibrosis. Hum. Pathol. 37, 352-360. doi: 10.1016/j.humpath.2005.11.020

Aghajanian, H., Kimura, T., Rurik, J. G., Hancock, A. S., Leibowitz, M. S., Li, L., et al. (2019). Targeting cardiac fibrosis with engineered T cells. Nature 573, 430-433.

Akhmetshina, A., Dees, C., Pileckyte, M., Maurer, B., Axmann, R., Jüngel, A., et al. (2008). Dual inhibition of c-abl and PDGF receptor signaling by dasatinib in upcoming studies. (5) The investigation on $\mathrm{Fb}$ subtypes in human subjects would definitely be a challenge due to the multifactorial causation of the disease development and tremendous heterogeneity that exists among patients. Thus, it is suggested to pay particular attention on strict selection of homogeneous clinical samples. Besides, analyzing samples from different points in the disease course to reduce bias caused by focusing only on the healthy and diseased states, might provide additional hints on disease progression (Shaw and Rognoni, 2020). (6) The current understanding of the origin of different $\mathrm{Fb}$ subtypes remains incomplete. Recent studies demonstrated the conversion of circulating myeloid cells to Fbs during wound healing, indicating a dedicate regulation of Fb fate switching (Sinha et al., 2018; Guerrero-Juarez et al., 2019). Further investigation into the evolution of $\mathrm{Fb}$ subtypes and factors influencing the Fbs plasticity could facilitate the development of potential therapeutic approaches in treating fibrotic diseases.

In the future, a more comprehensive transcriptomic, proteomic or genome-wide epigenetic profiling of $\mathrm{Fb}$ subtypes defined by different surface markers would be instrumental for a more in-depth understanding of the evolution and functional characteristics of each $\mathrm{Fb}$ subtype in tissue fibrosis. Hopefully, a more precise dissection of phenotype features and functional regulation of $\mathrm{Fb}$ subtypes would bring greater clinical insights for targeted treatment strategies for fibrotic diseases.

\section{AUTHOR CONTRIBUTIONS}

$\mathrm{XH}, \mathrm{QL}$, and TZ: conception and design. XH, YK, SG, CH, DS, and HM: collection and assembly of data. $\mathrm{XH}$ and $\mathrm{YK}$ : data analysis and interpretation and manuscript revision. $\mathrm{XH}, \mathrm{CH}, \mathrm{DS}$, $\mathrm{HM}$, and SG: graphic illustration. All authors wrote and approved the final manuscript.

\section{FUNDING}

This work was supported by grants from National Natural Science Foundation of China (81772086 and 82072177), "Two Hundred Talent" program, “Outstanding Youth Medical Talents" Shanghai "Rising Stars of Medical Talent" Youth Development Program, and Shanghai Jiao Tong University "Chenxing” Youth Development Program (Associate Professor Type A). and nilotinib for the treatment of dermal fibrosis. FASEB J. 22, 2214-2222. doi: 10.1096/fj.07-105627

Akhmetshina, A., Venalis, P., Dees, C., Busch, N., Zwerina, J., Schett, G., et al. (2009). Treatment with imatinib prevents fibrosis in different preclinical models of systemic sclerosis and induces regression of established fibrosis. Arthrit. Rheumat. 60, 219-224. doi: 10.1002/art.24186

Aroor, A. R., Habibi, J., Ford, D. A., Nistala, R., Lastra, G., Manrique, C., et al. (2015). Dipeptidyl peptidase-4 inhibition ameliorates Western diet-induced hepatic steatosis and insulin resistance through hepatic lipid remodeling and modulation of hepatic mitochondrial function. Diabetes 64, 1988-2001. doi: $10.2337 / \mathrm{db} 14-0804$ 
Ascensión, A. M., Fuertes-Álvarez, S., Ibañez-Solé, O., Izeta, A., and Araúzo-Bravo, M. J. (2020). Human dermal fibroblast subpopulations are conserved across single-Cell RNA sequencing studies. J. Invest. Dermatol. [Epub ahead of print]. doi: 10.1016/j.jid.2020.11.028

Avery, D., Govindaraju, P., Jacob, M., Todd, L., Monslow, J., and Puré, E. (2018). Extracellular matrix directs phenotypic heterogeneity of activated fibroblasts. Matrix Biol. 67, 90-106. doi: 10.1016/j.matbio.2017.12.003

Bando, Y. K., and Murohara, T. (2016). Heart failure as a comorbidity of diabetes: role of dipeptidyl peptidase 4. J. Atheroscl. Thromb. 23, 147-154. doi: 10.5551/ jat.33225

Bansal, R., Nagórniewicz, B., and Prakash, J. (2016). Clinical advancements in the targeted therapies against liver fibrosis. Mediat. Inflamm. 2016:7629724.

Bessi, V. L., Labbé, S. M., Huynh, D. N., Ménard, L., Jossart, C., Febbraio, M., et al. (2012). EP 80317, a selective CD36 ligand, shows cardioprotective effects against post-ischaemic myocardial damage in mice. Cardiovasc. Res. 96, 99-108. doi: $10.1093 / \mathrm{cvr} / \mathrm{cvs} 225$

Bocharov, A. V., Wu, T., Baranova, I. N., Birukova, A. A., Sviridov, D., Vishnyakova, T. G., et al. (2016). Synthetic amphipathic helical peptides targeting CD36 attenuate lipopolysaccharide-induced inflammation and acute lung injury. J. Immunol. 197, 611-619.

Borkham-Kamphorst, E., Stoll, D., Gressner, A. M., and Weiskirchen, R. (2004). Inhibitory effect of soluble PDGF-beta receptor in culture-activated hepatic stellate cells. Biochem. Biophys. Res. Commun. 317, 451-462. doi: 10.1016/j. bbrc.2004.03.064

Burnstock, G., Knight, G. E., and Greig, A. V. (2012). Purinergic signaling in healthy and diseased skin. J. Invest. Dermatol. $132(3 \mathrm{Pt} 1), 526-546$. doi: 10.1038/jid.2011.344

Busek, P., Mateu, R., Zubal, M., Kotackova, L., and Sedo, A. (2018). Targeting fibroblast activation protein in cancer - prospects and caveats. Front. Biosci. 23:1933-1968. doi: 10.2741/4682

Chen, W. C., Chang, Y. S., Hsu, H. P., Yen, M. C., Huang, H. L., Cho, C. Y., et al. (2015). Therapeutics targeting CD90-integrin-AMPK-CD133 signal axis in liver cancer. Oncotarget 6, 42923-42937. doi: 10.18632/oncotarget. 5976

Croft, A. P., Campos, J., Jansen, K., Turner, J. D., Marshall, J., Attar, M., et al. (2019). Distinct fibroblast subsets drive inflammation and damage in arthritis. Nature 570, 246-251. doi: 10.1038/s41586-019-1263-7

Czochra, P., Klopcic, B., Meyer, E., Herkel, J., Garcia-Lazaro, J. F., Thieringer, F., et al. (2006). Liver fibrosis induced by hepatic overexpression of PDGF-B in transgenic mice. J. Hepatol. 45, 419-428. doi: 10.1016/j.jhep.2006.04.010

Dienus, K., Bayat, A., Gilmore, B. F., and Seifert, O. (2010). Increased expression of fibroblast activation protein-alpha in keloid fibroblasts: implications for development of a novel treatment option. Arch. Dermatol. Res. 302, 725-731. doi: 10.1007/s00403-010-1084-x

Distler, J. H., Jüngel, A., Huber, L. C., Schulze-Horsel, U., Zwerina, J., Gay, R. E., et al. (2007). Imatinib mesylate reduces production of extracellular matrix and prevents development of experimental dermal fibrosis. Arthrit. Rheumat. 56, 311-322. doi: 10.1002/art.22314

Driskell, R. R., Lichtenberger, B. M., Hoste, E., Kretzschmar, K., Simons, B. D., Charalambous, M., et al. (2013). Distinct fibroblast lineages determine dermal architecture in skin development and repair. Nature 504, 277-281. doi: 10.1038/ nature 12783

Driskell, R. R., and Watt, F. M. (2015). Understanding fibroblast heterogeneity in the skin. Trends Cell Biol. 25, 92-99. doi: 10.1016/j.tcb.2014.10.001

Dulauroy, S., Di Carlo, S. E., Langa, F., Eberl, G., and Peduto, L. (2012). Lineage tracing and genetic ablation of ADAM12(+) perivascular cells identify a major source of profibrotic cells during acute tissue injury. Nat. Med. 18, 1262-1270. doi: $10.1038 / \mathrm{nm} .2848$

Egger, C., Cannet, C., Gérard, C., Suply, T., Ksiazek, I., Jarman, E., et al. (2017). Effects of the fibroblast activation protein inhibitor, PT100, in a murine model of pulmonary fibrosis. Eur. J. Pharmacol. 809, 64-72. doi: 10.1016/j.ejphar. 2017.05.022

Faas, M. M., Sáez, T., de Vos, P., and Extracellular, A. T. P. (2017). and adenosine: the Yin and Yang in immune responses? Mol. Aspects Med. 55, 9-19. doi: 10.1016/j.mam.2017.01.002

Fang, F., Yu, M., Cavanagh, M. M., Hutter Saunders, J., Qi, Q., Ye, Z., et al. (2016). Expression of CD39 on activated T cells impairs their survival in older individuals. Cell Rep. 14, 1218-1231. doi: 10.1016/j.celrep.2016.01.002
Febbraio, M., Hajjar, D. P., and Silverstein, R. L. (2001). CD36: a class B scavenger receptor involved in angiogenesis, atherosclerosis, inflammation, and lipid metabolism. J. Clin. Invest. 108, 785-791. doi: 10.1172/jci14006

Fernández, P., Perez-Aso, M., Smith, G., Wilder, T., Trzaska, S., Chiriboga, L., et al. (2013). Extracellular generation of adenosine by the ectonucleotidases CD39 and CD73 promotes dermal fibrosis. Am. J. Pathol. 183, 1740-1746. doi: 10.1016/j.ajpath.2013.08.024

Ferrari, D., Gambari, R., Idzko, M., Müller, T., Albanesi, C., Pastore, S., et al. (2016). Purinergic signaling in scarring. FASEB J. 30, 3-12. doi: 10.1096/fj.15-274563

Fiore, V. F., Strane, P. W., Bryksin, A. V., White, E. S., Hagood, J. S., and Barker, T. H. (2015). Conformational coupling of integrin and Thy-1 regulates Fyn priming and fibroblast mechanotransduction. J. Cell Biol. 211, 173-190. doi: $10.1083 /$ jcb. 201505007

Fleetwood, K., McCool, R., Glanville, J., Edwards, S. C., Gsteiger, S., Daigl, M., et al. (2017). Systematic review and network meta-analysis of idiopathic pulmonary fibrosis treatments. J. Manag. Care Special. Pharm. 23(3-b Suppl.), S5-S16.

Fraticelli, P., Gabrielli, B., Pomponio, G., Valentini, G., Bosello, S., Riboldi, P., et al. (2014). Low-dose oral imatinib in the treatment of systemic sclerosis interstitial lung disease unresponsive to cyclophosphamide: a phase II pilot study. Arthrit. Res. Ther. 16:R144.

Gangadharan Komala, M., Gross, S., Zaky, A., Pollock, C., and Panchapakesan, U. (2016). Saxagliptin reduces renal tubulointerstitial inflammation, hypertrophy and fibrosis in diabetes. Nephrology 21, 423-431. doi: 10.1111/nep.12618

Gerber, E. E., Gallo, E. M., Fontana, S. C., Davis, E. C., Wigley, F. M., Huso, D. L., et al. (2013). Integrin-modulating therapy prevents fibrosis and autoimmunity in mouse models of scleroderma. Nature 503, 126-130. doi: 10.1038 /nature12614

Giesen, C., Wang, H. A., Schapiro, D., Zivanovic, N., Jacobs, A., Hattendorf, B., et al. (2014). Highly multiplexed imaging of tumor tissues with subcellular resolution by mass cytometry. Nat. Methods 11, 417-422. doi: 10.1038/nmeth. 2869

Gilmore, B. F., Lynas, J. F., Scott, C. J., McGoohan, C., Martin, L., and Walker, B. (2006). Dipeptide proline diphenyl phosphonates are potent, irreversible inhibitors of seprase (FAPalpha). Biochem. Biophys. Res. Commun. 346, 436446. doi: 10.1016/j.bbrc.2006.05.175

Gordon, J., Udeh, U., Doobay, K., Magro, C., Wildman, H., Davids, M., et al. (2014). Imatinib mesylate (Gleevec ${ }^{\mathrm{TM}}$ ) in the treatment of diffuse cutaneous systemic sclerosis: results of a 24-month open label, extension phase, single-centre trial. Clin. Exp. Rheumatol. 32(6 Suppl. 86), 189-193.

Guerrero-Juarez, C. F., Dedhia, P. H., Jin, S., Ruiz-Vega, R., Ma, D., Liu, Y., et al. (2019). Single-cell analysis reveals fibroblast heterogeneity and myeloid-derived adipocyte progenitors in murine skin wounds. Nat. Commun. 10:650.

Hansen, T. C., Woeller, C. F., Lacy, S. H., Koltz, P. F., Langstein, H. N., and Phipps, R. P. (2017). Thyl (CD90) expression is elevated in radiationinduced periprosthetic capsular contracture: implication for novel therapeutics. Plast. Reconstruct. Surg. 140, 316-326. doi: 10.1097/prs.000000000000 3542

Hao, Z. M., Fan, X. B., Li, S., Lv, Y. F., Su, H. Q., Jiang, H. P., et al. (2012). Vaccination with platelet-derived growth factor B kinoids inhibits CCl4induced hepatic fibrosis in mice. J. Pharmacol. Exp. Therap. 342, 835-842. doi: $10.1124 /$ jpet.112.194357

Harvey, T., Flamenco, S., and Fan, C. M. (2019). A Tppp3(+)Pdgfra(+) tendon stem cell population contributes to regeneration and reveals a shared role for PDGF signalling in regeneration and fibrosis. Nat. Cell Biol. 21, 1490-1503. doi: 10.1038/s41556-019-0417-z

Hayes, B. J., Riehle, K. J., Shimizu-Albergine, M., Bauer, R. L., Hudkins, K. L., Johansson, F., et al. (2014). Activation of platelet-derived growth factor receptor alpha contributes to liver fibrosis. PLoS One 9:e92925. doi: 10.1371/journal. pone.0092925

Heinzelmann, K., Lehmann, M., Gerckens, M., Noskovičová, N., Frankenberger, M., Lindner, M., et al. (2018). Cell-surface phenotyping identifies CD36 and CD97 as novel markers of fibroblast quiescence in lung fibrosis. Am. J. Physiol. Lung Cell. Mol. Physiol. 315, L682-L696.

Higashi, T., Friedman, S. L., and Hoshida, Y. (2017). Hepatic stellate cells as key target in liver fibrosis. Adv. Drug Deliv. Rev. 121, 27-42. doi: 10.1016/j.addr. 2017.05.007

Ho, J. D., Chung, H. J., Ms Barron, A., Ho, D. A., Sahni, D., Browning, J. L., et al. (2019). Extensive CD34-to-CD90 fibroblast transition defines 
regions of cutaneous reparative, hypertrophic, and keloidal scarring. Am. J. Dermatopathol. 41, 16-28. doi: 10.1097/dad.0000000000001254

$\mathrm{Hu}, \mathrm{M}$. S., and Longaker, M. T. (2016). Dipeptidyl peptidase-4, wound healing, scarring, and fibrosis. Plast. Reconstruct. Surg. 138, 1026-1031. doi: 10.1097/ prs. 0000000000002634

Ibegbu, C. C., Xu, Y. X., Fillos, D., Radziewicz, H., Grakoui, A., and Kourtis, A. P. (2009). Differential expression of CD26 on virus-specific CD8(+) T cells during active, latent and resolved infection. Immunology 126, 346-353. doi: 10.1111/j.1365-2567.2008.02899.x

Ieronimakis, N., Hays, A., Prasad, A., Janebodin, K., Duffield, J. S., and Reyes, M. (2016). PDGFR $\alpha$ signalling promotes fibrogenic responses in collagenproducing cells in Duchenne muscular dystrophy. J. Pathol. 240, 410-424. doi: 10.1002/path.4801

Ishiura, Y., Kotani, N., Yamashita, R., Yamamoto, H., Kozutsumi, Y., and Honke, K. (2010). Anomalous expression of Thyl (CD90) in B-cell lymphoma cells and proliferation inhibition by anti-Thyl antibody treatment. Biochem. Biophys. Res. Commun. 396, 329-334. doi: 10.1016/j.bbrc.2010.04.092

Itou, M., Kawaguchi, T., Taniguchi, E., and Sata, M. (2013). Dipeptidyl peptidase-4: a key player in chronic liver disease. World J. Gastroenterol. 19, 2298-2306.

Jacob, M., Chang, L., and Puré, E. (2012). Fibroblast activation protein in remodeling tissues. Curr. Mol. Med. 12, 1220-1243. doi: 10.2174/ 156652412803833607

Jiang, D., and Rinkevich, Y. (2018). Defining skin fibroblastic cell types beyond CD90. Front. Cell Dev. Biol. 6:133. doi: 10.3389/fcell.2018.00133

Jiang, D., and Rinkevich, Y. (2020). Scars or regeneration?-Dermal fibroblasts as drivers of diverse skin wound responses. Int. J. Mol. Sci. 21:617. doi: 10.3390/ ijms 21020617

Jung, Y. A., Choi, Y. K., Jung, G. S., Seo, H. Y., Kim, H. S., Jang, B. K., et al. (2014). Sitagliptin attenuates methionine/choline-deficient diet-induced steatohepatitis. Diabetes Res. Clin. Pract. 105, 47-57. doi: 10.1016/j.diabres. 2014.04.028

Kaji, K., Yoshiji, H., Ikenaka, Y., Noguchi, R., Aihara, Y., Douhara, A., et al. (2014). Dipeptidyl peptidase-4 inhibitor attenuates hepatic fibrosis via suppression of activated hepatic stellate cell in rats. J. Gastroenterol. 49, 481-491. doi: 10.1007/ s00535-013-0783-4

Kalluri, R., and Zeisberg, M. (2006). Fibroblasts in cancer. Nat. Rev. Cancer 6, 392-401.

Kanasaki, K., Shi, S., Kanasaki, M., He, J., Nagai, T., Nakamura, Y., et al. (2014). 4 inhibition ameliorates kidney fibrosis in streptozotocin-induced diabetic mice by inhibiting endothelial-to-mesenchymal transition in a therapeutic regimen. Diabetes 63, 2120-2131. doi: 10.2337/db13-1029

Kang, H. M., Ahn, S. H., Choi, P., Ko, Y. A., Han, S. H., Chinga, F., et al. (2015). Defective fatty acid oxidation in renal tubular epithelial cells has a key role in kidney fibrosis development. Nat. Med. 21, 37-46. doi: 10.1038/nm.3762

Katsumata, L. W., Miyajima, A., and Itoh, T. (2017). Portal fibroblasts marked by the surface antigen Thyl contribute to fibrosis in mouse models of cholestatic liver injury. Hepatol. Commun. 1, 198-214. doi: 10.1002/hep4.1023

Kavian, N., Servettaz, A., Marut, W., Nicco, C., Chéreau, C., Weill, B., et al. (2012). Sunitinib inhibits the phosphorylation of platelet-derived growth factor receptor $\beta$ in the skin of mice with scleroderma-like features and prevents the development of the disease. Arthrit. Rheum. 64, 1990-2000. doi: 10.1002/art. 34354

Kay, J., and High, W. A. (2008). Imatinib mesylate treatment of nephrogenic systemic fibrosis. Arthrit. Rheum. 58, 2543-2548. doi: 10.1002/art.23696

Kelly, T. (2005). Fibroblast activation protein-alpha and dipeptidyl peptidase IV (CD26): cell-surface proteases that activate cell signaling and are potential targets for cancer therapy. Drug Resist. Updates 8, 51-58. doi: 10.1016/j.drup. 2005.03.002

Khalil, R., Shata, A., Abd El-Kader, E. M., Sharaf, H., Abdo, W. S., Amin, N. A., et al. (2020). Vildagliptin, a DPP-4 inhibitor, attenuates carbon tetrachlorideinduced liver fibrosis by targeting ERK1/2, p38 $\alpha$, and NF-кB signaling. Toxicol. Appl. Pharmacol. 407, 115246. doi: 10.1016/j.taap.2020.115246

Khanna, D., Saggar, R., Mayes, M. D., Abtin, F., Clements, P. J., Maranian, P., et al. (2011). A one-year, phase I/IIa, open-label pilot trial of imatinib mesylate in the treatment of systemic sclerosis-associated active interstitial lung disease. Arthrit. Rheum. 63, 3540-3546. doi: 10.1002/art.30548

Kim, M. J., Kim, N. Y., Jung, Y. A., Lee, S., Jung, G. S., Kim, J. G., et al. (2020). Evogliptin, a Dipeptidyl Peptidase-4 inhibitor, attenuates renal fibrosis caused by unilateral ureteral obstruction in mice. Diabetes Metab. J. 44, 186-192. doi: 10.4093/dmj.2018.0271

Kimura, T., Monslow, J., Klampatsa, A., Leibowitz, M., Sun, J., Liousia, M., et al. (2019). Loss of cells expressing fibroblast activation protein has variable effects in models of TGF- $\beta$ and chronic bleomycin-induced fibrosis. Am. J. Physiol. Lung Cell. Mol. Physiol. 317, L271-L282.

Klinkhammer, B. M., Floege, J., and Boor, P. (2018). PDGF in organ fibrosis. Mol. Aspects Med. 62, 44-62. doi: 10.1016/j.mam.2017.11.008

Kocabayoglu, P., Lade, A., Lee, Y. A., Dragomir, A. C., Sun, X., Fiel, M. I., et al. (2015). $\beta$-PDGF receptor expressed by hepatic stellate cells regulates fibrosis in murine liver injury, but not carcinogenesis. J. Hepatol. 63, 141-147. doi: 10.1016/j.jhep.2015.01.036

Korosec, A., Frech, S., Gesslbauer, B., Vierhapper, M., Radtke, C., Petzelbauer, P., et al. (2019). Lineage identity and location within the dermis determine the function of papillary and reticular fibroblasts in human skin. J. Invest. Dermatol. 139, 342-351. doi: 10.1016/j.jid.2018.07.033

Kostallari, E., Hirsova, P., Prasnicka, A., Verma, V. K., Yaqoob, U., Wongjarupong, N., et al. (2018). Hepatic stellate cell-derived platelet-derived growth factor receptor-alpha-enriched extracellular vesicles promote liver fibrosis in mice through SHP2. Hepatology 68, 333-348. doi: 10.1002/hep.29803

Kuai, J., Mosyak, L., Brooks, J., Cain, M., Carven, G. J., Ogawa, S., et al. (2015). Characterization of binding mode of action of a blocking antiplatelet-derived growth factor (PDGF)-B monoclonal antibody, MOR8457, reveals conformational flexibility and avidity needed for PDGF-BB to bind PDGF receptor- $\beta$. Biochemistry 54, 1918-1929. doi: 10.1021/bi501 5425

Künzli, B. M., Nuhn, P., Enjyoji, K., Banz, Y., Smith, R. N., Csizmadia, E., et al. (2008). Disordered pancreatic inflammatory responses and inhibition of fibrosis in CD39-null mice. Gastroenterology 134, 292-305. doi: 10.1053/j.gastro.2007. 10.030

Lee, M., Shin, E., Bae, J., Cho, Y., Lee, J. Y., Lee, Y. H., et al. (2020). Dipeptidyl peptidase-4 inhibitor protects against non-alcoholic steatohepatitis in mice by targeting TRAIL receptor-mediated lipoapoptosis via modulating hepatic dipeptidyl peptidase-4 expression. Sci. Rep. 10:19429.

Levy, M. T., McCaughan, G. W., Marinos, G., and Gorrell, M. D. (2002). Intrahepatic expression of the hepatic stellate cell marker fibroblast activation protein correlates with the degree of fibrosis in hepatitis $C$ virus infection. Liver 22, 93-101. doi: 10.1034/j.1600-0676.2002.01503.X

Li, Y., Zhang, J., Zhou, Q., Wang, H., Xie, S., Yang, X., et al. (2019). Linagliptin inhibits high glucose-induced transdifferentiation of hypertrophic scar-derived fibroblasts to myofibroblasts via IGF/Akt/mTOR signalling pathway. Exp. Dermatol. 28, 19-27. doi: 10.1111/exd.13800

Liu, Y., Wang, Z., Kwong, S. Q., Lui, E. L. H., Friedman, S. L., Li, F. R., et al. (2011). Inhibition of PDGF, TGF- $\beta$, and Abl signaling and reduction of liver fibrosis by the small molecule Bcr-Abl tyrosine kinase antagonist Nilotinib. J. Hepatol. 55, 612-625. doi: 10.1016/j.jhep.2010.11.035

Long, M., Cai, L., Li, W., Zhang, L., Guo, S., Zhang, R., et al. (2018). DPP-4 inhibitors improve diabetic wound healing via direct and indirect promotion of epithelial-mesenchymal transition and reduction of scarring. Diabetes 67, 518-531.

Lynch, M. D., and Watt, F. M. (2018). Fibroblast heterogeneity: implications for human disease. J. Clin. Invest. 128, 26-35. doi: 10.1172/jci93555

Mah, W., Jiang, G., Olver, D., Gallant-Behm, C., Wiebe, C., Hart, D. A., et al. (2017). Elevated CD26 expression by skin fibroblasts distinguishes a profibrotic phenotype involved in scar formation compared to gingival fibroblasts. Am. J. Pathol. 187, 1717-1735. doi: 10.1016/j.ajpath.2017.04.017

Marcelin, G., Ferreira, A., Liu, Y., Atlan, M., Aron-Wisnewsky, J., Pelloux, V., et al. (2017). A PDGFR $\alpha$-mediated switch toward CD9(high) adipocyte progenitors controls obesity-induced adipose tissue fibrosis. Cell Metab. 25, 673-685. doi: 10.1016/j.cmet.2017.01.010

Marleau, S., Harb, D., Bujold, K., Avallone, R., Iken, K., Wang, Y., et al. (2005). EP 80317, a ligand of the CD36 scavenger receptor, protects apolipoprotein E-deficient mice from developing atherosclerotic lesions. FASEB J. 19, 18691871. doi: 10.1096/fj.04-3253fje

Marques, A. P., Cunha-Santos, J., Leal, H., Sousa-Ferreira, L., Pereira de Almeida, L., Cavadas, C., et al. (2018). Dipeptidyl peptidase IV (DPP-IV) inhibition prevents fibrosis in adipose tissue of obese mice. Biochim. Biophys. Acta Gen. Subj. 1862, 403-413. doi: 10.1016/j.bbagen.2017.11.012 
Mejias, M., Garcia-Pras, E., Tiani, C., Miquel, R., Bosch, J., and Fernandez, M. (2009). Beneficial effects of sorafenib on splanchnic, intrahepatic, and portocollateral circulations in portal hypertensive and cirrhotic rats. Hepatology 49, 1245-1256. doi: 10.1002/hep.22758

Nazari, B., Rice, L. M., Stifano, G., Barron, A. M., Wang, Y. M., Korndorf, T., et al. (2016). Altered dermal fibroblasts in systemic sclerosis display podoplanin and CD90. Am. J. Pathol. 186, 2650-2664. doi: 10.1016/j.ajpath.2016.06.020

Nicola, T., Hagood, J. S., James, M. L., Macewen, M. W., Williams, T. A., Hewitt, M. M., et al. (2009). Loss of Thy-1 inhibits alveolar development in the newborn mouse lung. Am. J. Physiol. Lung Cell. Mol. Physiol. 296, L738-L750.

Okamura, D. M., Pennathur, S., Pasichnyk, K., López-Guisa, J. M., Collins, S., Febbraio, M., et al. (2009). CD36 regulates oxidative stress and inflammation in hypercholesterolemic CKD. J. Am. Soc. Nephrol. 20, 495-505. doi: 10.1681/ asn.2008010009

Olson, L. E., and Soriano, P. (2009). Increased PDGFRalpha activation disrupts connective tissue development and drives systemic fibrosis. Dev. Cell 16, 303313. doi: 10.1016/j.devcel.2008.12.003

Ospelt, C., Mertens, J. C., Jüngel, A., Brentano, F., Maciejewska-Rodriguez, H., Huber, L. C., et al. (2010). Inhibition of fibroblast activation protein and dipeptidylpeptidase 4 increases cartilage invasion by rheumatoid arthritis synovial fibroblasts. Arthrit. Rheum. 62, 1224-1235. doi: 10.1002/art.27395

Ostendorf, T., van Roeyen, C. R., Peterson, J. D., Kunter, U., Eitner, F., Hamad, A. J., et al. (2003). A fully human monoclonal antibody (CR002) identifies PDGF-D as a novel mediator of mesangioproliferative glomerulonephritis. J. Am. Soc. Nephrol. 14, 2237-2247. doi: 10.1097/01.asn.0000083393.00959.02

Östman, A. (2017). PDGF receptors in tumor stroma: biological effects and associations with prognosis and response to treatment. Adv. Drug Deliv. Rev. 121, 117-123. doi: 10.1016/j.addr.2017.09.022

Panchapakesan, U., and Pollock, C. (2015). The role of dipeptidyl peptidase 4 inhibitors in diabetic kidney disease. Front. Immunol. 6:443. doi: 10.1042/ CS20180031

Papadopoulos, N., Lennartsson, J., and The, P. D. G. F. (2018). /PDGFR pathway as a drug target. Mol. Aspects Med. 62, 75-88. doi: 10.1016/j.mam.2017.11.007

Patel, P. M., Jones, V. A., Kridin, K., and Amber, K. T. (2020). The role of Dipeptidyl Peptidase-4 in cutaneous disease. Exp. Dermatol. 30, 304-318. doi: 10.1111/exd. 14228

Pennathur, S., Pasichnyk, K., Bahrami, N. M., Zeng, L., Febbraio, M., Yamaguchi, I., et al. (2015). The macrophage phagocytic receptor CD36 promotes fibrogenic pathways on removal of apoptotic cells during chronic kidney injury. Am. J. Pathol. 185, 2232-2245. doi: 10.1016/j.ajpath.2015.04.016

Perrot, I., Michaud, H. A., Giraudon-Paoli, M., Augier, S., Docquier, A., Gros, L., et al. (2019). Blocking antibodies targeting the CD39/CD73 immunosuppressive pathway unleash immune responses in combination cancer therapies. Cell Rep. 27, 2411.e9-2425.e9.

Philippeos, C., Telerman, S. B., Oulès, B., Pisco, A. O., Shaw, T. J., Elgueta, R., et al. (2018). Spatial and single-cell transcriptional profiling identifies functionally distinct human dermal fibroblast subpopulations. J. Invest. Dermatol. 138, 811-825. doi: 10.1016/j.jid.2018.01.016

Pietras, K., Sjöblom, T., Rubin, K., Heldin, C. H., and Ostman, A. (2003). PDGF receptors as cancer drug targets. Cancer Cell 3, 439-443. doi: 10.1016/s15356108(03)00089-8

Pontén, A., Li, X., Thorén, P., Aase, K., Sjöblom, T., Ostman, A., et al. (2003). Transgenic overexpression of platelet-derived growth factor- $\mathrm{C}$ in the mouse heart induces cardiac fibrosis, hypertrophy, and dilated cardiomyopathy. Am. J. Pathol. 163, 673-682. doi: 10.1016/s0002-9440(10)63694-2

Prakadan, S. M., Shalek, A. K., and Weitz, D. A. (2017). Scaling by shrinking: empowering single-cell 'omics' with microfluidic devices. Nat. Rev. Genet. 18, 345-361. doi: 10.1038/nrg.2017.15

Prey, S., Ezzedine, K., Doussau, A., Grandoulier, A. S., Barcat, D., Chatelus, E., et al. (2012). Imatinib mesylate in scleroderma-associated diffuse skin fibrosis: a phase II multicentre randomized double-blinded controlled trial. Br. J. Dermatol. 167, 1138-1144. doi: 10.1111/j.1365-2133.2012.11186.x

Rabinowitz, J. D., and Mutlu, G. M. (2019). A metabolic strategy to reverse fibrosis? Nat. Metab. 1, 12-13. doi: 10.1038/s42255-018-0013-8

Ramachandran, P., Dobie, R., Wilson-Kanamori, J. R., Dora, E. F., Henderson, B. E. P., Luu, N. T., et al. (2019). Resolving the fibrotic niche of human liver cirrhosis at single-cell level. Nature 575, 512-518. doi: 10.1038/s41586-0191631-3
Rege, T. A., and Hagood, J. S. (2006). Thy-1 as a regulator of cell-cell and cell-matrix interactions in axon regeneration, apoptosis, adhesion, migration, cancer, and fibrosis. FASEB J. 20, 1045-1054. doi: 10.1096/fj.05-54 $60 \mathrm{rev}$

Rinkevich, Y., Walmsley, G. G., Hu, M. S., Maan, Z. N., Newman, A. M., Drukker, M., et al. (2015). Skin fibrosis. Identification and isolation of a dermal lineage with intrinsic fibrogenic potential. Science 348:aaa2151. doi: 10.1126/science. aaa2151

Roberts, V., Campbell, D. J., Lu, B., Chia, J., Cowan, P. J., and Dwyer, K. M. (2017). The differential effect of apyrase treatment and hCD39 overexpression on chronic renal fibrosis after ischemia-reperfusion injury. Transplantation 101, e194-e204.

Roberts, V., Lu, B., Chia, J., Cowan, P. J., and Dwyer, K. M. (2016). CD39 overexpression does not attenuate renal fibrosis in the unilateral ureteric obstructive model of chronic kidney disease. Purinerg. Signal. 12, 653-660. doi: 10.1007/s11302-016-9528-1

Rothweiler, S., Feldbrügge, L., Jiang, Z. G., Csizmadia, E., Longhi, M. S., Vaid, K., et al. (2019). Selective deletion of ENTPD1/CD39 in macrophages exacerbates biliary fibrosis in a mouse model of sclerosing cholangitis. Purinerg. Signal. 15, 375-385. doi: 10.1007/s11302-019-09664-3

Sanders, Y. Y., Pardo, A., Selman, M., Nuovo, G. J., Tollefsbol, T. O., Siegal, G. P., et al. (2008). Thy-1 promoter hypermethylation: a novel epigenetic pathogenic mechanism in pulmonary fibrosis. Am. J. Respir. Cell Mol. Biol. 39, 610-618. doi: 10.1165/rcmb.2007-0322oc

Santini, M. P., Malide, D., Hoffman, G., Pandey, G., D’Escamard, V., NomuraKitabayashi, A., et al. (2020). Tissue-resident PDGFR $\alpha(+)$ progenitor cells contribute to fibrosis versus healing in a context- and spatiotemporally dependent manner. Cell Rep. 30, 555.e7-570.e7.

Seo, J. B., Choi, Y. K., Woo, H. I., Jung, Y. A., Lee, S., Lee, S., et al. (2019). Gemigliptin attenuates renal fibrosis through down-regulation of the NLRP3 inflammasome. Diabetes Metab. J. 43, 830-839. doi: 10.4093/dmj.2018. 0181

Shaikh, M. V., Kala, M., and Nivsarkar, M. (2016). CD90 a potential cancer stem cell marker and a therapeutic target. Cancer Biomark. 16, 301-307. doi: 10. 3233/cbm- 160590

Shaker, M. E., Salem, H. A., Shiha, G. E., and Ibrahim, T. M. (2011). Nilotinib counteracts thioacetamide-induced hepatic oxidative stress and attenuates liver fibrosis progression. Fund. Clin. Pharmacol. 25, 248-257. doi: 10.1111/j.14728206.2010.00824.x

Shaw, T. J., and Rognoni, E. (2020). Dissecting fibroblast heterogeneity in health and fibrotic disease. Curr. Rheumatol. Rep. 22:33.

Sinha, M., Sen, C. K., Singh, K., Das, A., Ghatak, S., Rhea, B., et al. (2018). Direct conversion of injury-site myeloid cells to fibroblast-like cells of granulation tissue. Nat. Commun. 9:936.

Soare, A., Györfi, H. A., Matei, A. E., Dees, C., Rauber, S., Wohlfahrt, T., et al. (2020). Dipeptidylpeptidase 4 as a marker of activated fibroblasts and a potential target for the treatment of fibrosis in systemic sclerosis. Arthrit. Rheumatol. 72, 137-149. doi: 10.1002/art.41058

Soria, A., Cario-André, M., Lepreux, S., Rezvani, H. R., Pasquet, J. M., Pain, C., et al. (2008). The effect of imatinib (Glivec) on scleroderma and normal dermal fibroblasts: a preclinical study. Dermatology 216, 109-117. doi: 10.1159/ 000111507

Souza, A. C., Bocharov, A. V., Baranova, I. N., Vishnyakova, T. G., Huang, Y. G., Wilkins, K. J., et al. (2016). Antagonism of scavenger receptor CD36 by 5A peptide prevents chronic kidney disease progression in mice independent of blood pressure regulation. Kidney Int. 89, 809-822. doi: 10.1016/j.kint.2015.12. 043

Spiera, R. F., Gordon, J. K., Mersten, J. N., Magro, C. M., Mehta, M., Wildman, H. F., et al. (2011). Imatinib mesylate (Gleevec) in the treatment of diffuse cutaneous systemic sclerosis: results of a 1-year, phase IIa, single-arm, openlabel clinical trial. Ann. Rheum. Dis. 70, 1003-1009. doi: 10.1136/ard.2010. 143974

Suwanai, H., Watanabe, R., Sato, M., Odawara, M., and Matsumura, H. (2020). Dipeptidyl peptidase- 4 inhibitor reduces the risk of developing hypertrophic scars and keloids following median sternotomy in diabetic patients: a nationwide retrospective cohort study using the national database of health insurance claims of Japan. Plast. Reconstruct. Surg. 146, 83-89. doi: 10.1097/ prs.0000000000006904 
Suzuki, T., Tada, Y., Gladson, S., Nishimura, R., Shimomura, I., Karasawa, S., et al. (2017). Vildagliptin ameliorates pulmonary fibrosis in lipopolysaccharideinduced lung injury by inhibiting endothelial-to-mesenchymal transition. Respir. Res. 18:177.

Sweetwyne, M. T., and Murphy-Ullrich, J. E. (2012). Thrombospondin1 in tissue repair and fibrosis: TGF- $\beta$-dependent and independent mechanisms. Matrix Biol. 31, 178-186. doi: 10.1016/j.matbio.2012.01.006

Tabib, T., Morse, C., Wang, T., Chen, W., and Lafyatis, R. (2018). SFRP2/DPP4 and FMO1/LSP1 define major fibroblast populations in human skin. J. Invest. Dermatol. 138, 802-810. doi: 10.1016/j.jid.2017.09.045

Takagaki, Y., Koya, D., and Kanasaki, K. (2017). Dipeptidyl peptidase-4 inhibition and renoprotection: the role of antifibrotic effects. Curr. Opin. Nephrol. Hypertens. 26, 56-66. doi: 10.1097/mnh.0000000000000291

Tan, C., Jiang, M., Wong, S. S., Espinoza, C. R., Kim, C., Li, X., et al. (2019). Soluble Thy-1 reverses lung fibrosis via its integrin-binding motif. JCI insight 4:e131152.

Thielitz, A., Vetter, R. W., Schultze, B., Wrenger, S., Simeoni, L., Ansorge, S., et al. (2008). Inhibitors of dipeptidyl peptidase IV-like activity mediate antifibrotic effects in normal and keloid-derived skin fibroblasts. J. Invest. Dermatol. 128, 855-866. doi: 10.1038/sj.jid.5701104

Tillmanns, J., Hoffmann, D., Habbaba, Y., Schmitto, J. D., Sedding, D., Fraccarollo, D., et al. (2015). Fibroblast activation protein alpha expression identifies activated fibroblasts after myocardial infarction. J. Mol. Cell. Cardiol. 87, 194203. doi: 10.1016/j.yjmcc.2015.08.016

Truffi, M., Sorrentino, L., Monieri, M., Fociani, P., Mazzucchelli, S., Bonzini, M., et al. (2018). Inhibition of fibroblast activation protein restores a balanced extracellular matrix and reduces fibrosis in crohn's disease strictures ex vivo. Inflamm. Bowel Dis. 24, 332-345. doi: 10.1093/ibd/izx008

Uchii, M., Kimoto, N., Sakai, M., Kitayama, T., and Kunori, S. (2016). Glucoseindependent renoprotective mechanisms of the tissue dipeptidyl peptidase- 4 inhibitor, saxagliptin, in Dahl salt-sensitive hypertensive rats. Eur. J. Pharmacol. 783, 56-63. doi: 10.1016/j.ejphar.2016.04.005

Vickovic, S., Eraslan, G., Salmén, F., Klughammer, J., Stenbeck, L., Schapiro, D., et al. (2019). High-definition spatial transcriptomics for in situ tissue profiling. Nat. Methods 16, 987-990. doi: 10.1038/s41592-019-0548-y

Vorstandlechner, V., Laggner, M., Kalinina, P., Haslik, W., Radtke, C., Shaw, L., et al. (2020). Deciphering the functional heterogeneity of skin fibroblasts using single-cell RNA sequencing. FASEB J. 34, 3677-3692. doi: 10.1096/fj. $201902001 \mathrm{rr}$

Vuorinen, K., Gao, F., Oury, T. D., Kinnula, V. L., and Myllärniemi, M. (2007). Imatinib mesylate inhibits fibrogenesis in asbestos-induced interstitial pneumonia. Exp. Lung Res. 33, 357-373. doi: 10.1080/01902140701634827

Wang, X., Chen, Y., Lv, L., and Chen, J. (2009). Silencing CD36 gene expression results in the inhibition of latent-TGF-betal activation and suppression of silica-induced lung fibrosis in the rat. Respir. Res. 10:36.

Wang, X. M., Yu, D. M., McCaughan, G. W., and Gorrell, M. D. (2005). Fibroblast activation protein increases apoptosis, cell adhesion, and migration by the LX-2 human stellate cell line. Hepatology 42, 935-945. doi: 10.1002/hep.20853

Wang, Y. M., McRae, J. L., Robson, S. C., Cowan, P. J., Zhang, G. Y., Hu, M., et al. (2012). cells participate in CD39-mediated protection from renal injury. Eur. J. Immunol. 42, 2441-2451. doi: 10.1002/eji.201242434

Wei, K., Korsunsky, I., Marshall, J. L., Gao, A., Watts, G. F. M., Major, T., et al. (2020). Notch signalling drives synovial fibroblast identity and arthritis pathology. Nature 582, 259-264. doi: 10.1038/s41586-020-2222-z
Worthen, C. A., Cui, Y., Orringer, J. S., Johnson, T. M., Voorhees, J. J., and Fisher, G. J. (2020). CD26 identifies a subpopulation of fibroblasts that produce the majority of collagen during wound healing in human skin. J. Invest. Dermatol. 140, 2515.e3-2524.e3.

Xin, Y., Wang, X., Zhu, M., Qu, M., Bogari, M., Lin, L., et al. (2017). Expansion of CD26 positive fibroblast population promotes keloid progression. Exp. Cell Res. 356, 104-113.

Xu, J., Wang, J., He, M., Han, H., Xie, W., Wang, H., et al. (2018). Dipeptidyl peptidase IV (DPP-4) inhibition alleviates pulmonary arterial remodeling in experimental pulmonary hypertension. Lab. Invest. 98, 1333-1346. doi: 10 . 1038/s41374-018-0080-1

Yang, R., Elsaadi, S., Misund, K., Abdollahi, P., Vandsemb, E. N., Moen, S. H., et al. (2020). Conversion of ATP to adenosine by CD39 and CD73 in multiple myeloma can be successfully targeted together with adenosine receptor A2A blockade. J. Immunother. Cancer 8:e000610. doi: 10.1136/jitc-2020-00 0610

Yang, X., Okamura, D. M., Lu, X., Chen, Y., Moorhead, J., Varghese, Z., et al. (2017). CD36 in chronic kidney disease: novel insights and therapeutic opportunities. Nat. Rev. Nephrol. 13, 769-781. doi: 10.1038/nrneph.2017.126

Yang, Y. L., Lin, S. H., Chuang, L. Y., Guh, J. Y., Liao, T. N., Lee, T. C., et al. (2007). CD36 is a novel and potential anti-fibrogenic target in albumin-induced renal proximal tubule fibrosis. J. Cell. Biochem. 101, 735-744. doi: 10.1002/jcb.21236 Yehualaeshet, T., O'Connor, R., Begleiter, A., Murphy-Ullrich, J. E., Silverstein, R., and Khalil, N. (2000). A CD36 synthetic peptide inhibits bleomycin-induced pulmonary inflammation and connective tissue synthesis in the rat. Am.J. Respir. Cell Mol. Biol. 23, 204-212. doi: 10.1165/ajrcmb.23.2.4089

Ying, H. Z., Chen, Q., Zhang, W. Y., Zhang, H. H., Ma, Y., Zhang, S. Z., et al. (2017). PDGF signaling pathway in hepatic fibrosis pathogenesis and therapeutics (Review). Mol. Med. Rep. 16, 7879-7889. doi: 10.3892/mmr.2017. 7641

Yoshida, S., Ikenaga, N., Liu, S. B., Peng, Z. W., Chung, J., Sverdlov, D. Y., et al. (2014). Extrahepatic platelet-derived growth factor- $\beta$, delivered by platelets, promotes activation of hepatic stellate cells and biliary fibrosis in mice. Gastroenterology 147, 1378-1392. doi: 10.1053/j.gastro.2014.08.038

Zhang, H., Sun, D., Wang, G., Cui, S., Field, R. A., Li, J., et al. (2019). Alogliptin alleviates liver fibrosis via suppression of activated hepatic stellate cell. Biochem. Biophys. Res. Commun. 511, 387-393. doi: 10.1016/j.bbrc.2019.02.065

Zhao, X., Psarianos, P., Ghoraie, L. S., Yip, K., Goldstein, D., Gilbert, R., et al. (2019). Metabolic regulation of dermal fibroblasts contributes to skin extracellular matrix homeostasis and fibrosis. Nat. Metab. 1, 147-157. doi: 10.1038/s42255-018-0008-5

Conflict of Interest: The authors declare that the research was conducted in the absence of any commercial or financial relationships that could be construed as a potential conflict of interest.

Copyright (C) 2021 Huang, Khoong, Han, Su, Ma, Gu, Li and Zan. This is an openaccess article distributed under the terms of the Creative Commons Attribution License (CC BY). The use, distribution or reproduction in other forums is permitted, provided the original author(s) and the copyright owner(s) are credited and that the original publication in this journal is cited, in accordance with accepted academic practice. No use, distribution or reproduction is permitted which does not comply with these terms. 